\title{
Solvent effect in photo-ionic cells
}

\author{
Elena Vladimirova, Pekka Peljo*, Hubert H. Girault \\ Laboratoire d'Electrochimie Physique et Analytique (LEPA), École Polytechnique Fédérale de Lausanne (EPFL), Rue de l'Industrie 17, CH-1951 Sion, Switzerland
}

\section{A R T I C L E I N F O}

\section{Keywords:}

Photo-ionic cells

Solar energy conversion

Biphasic flow battery

Ion transfer

Liquid-liquid interfaces

\begin{abstract}
A B S T R A C T
Photo-ionic cells convert solar energy into redox fuels. Unlike in photovoltaic devices where the photo-induced charge transfer reactions occur at an electrode, the photoreaction takes place in one bulk solution of a biphasic liquid-liquid system, and the charge separation is realised by the transfer of one of the photoproducts into the adjacent phase to avoid recombination. After separation of the two phases, the redox fuels can be stored and then converted to electricity on demand with a biphasic fuel cell. Here, we compared the effect of the two organic solvents, 1,2-dichloroethane and propylene carbonate, on the performance of the photo-ionic cell. By replacing 1,2-dichloroethane, the maximum cell voltage was increased to $0.6 \mathrm{~V}$. Additionally, propylene carbonate helps to reduce aggregation of dyes and it shows faster kinetics for the photoreaction.
\end{abstract}

\section{Introduction}

Solar energy conversion is one the global challenges for a sustainable economy. At present, two major routes are being followed: photovoltaic (PV) systems to generate electricity [1] and solar thermal collectors to generate heat [2]. State-of-the-art semiconductor based PV cells can reach conversion efficiencies of 20 to even $30 \%$ [1], and dyesensitized solar cells can reach conversion efficiencies of 11 up to $14 \%$ [3-5] at the laboratory scale. However, all PV technologies must immediately distribute the produced electricity either to a storage system or to the electrical grid, irrespective of demand. A common electricity storage in mountain regions like Switzerland is pumped-hydro, where excess electricity is used to pump water to reservoirs located in high areas [6]. The electricity is then regained as hydropower with a turnaround yield of about $80 \%$. This, however, is unpractical in many parts of the world. An upcoming strategy is based on the use of Megawatt batteries, either solid state like Li-Ion [6] or redox flow such as the all Vanadium redox flow battery [7-10].

Another strategy is to directly produce solar fuels. Various concepts have been proposed, like photo-biological solar fuel production with different micro-organisms [11], artificial photosynthesis in molecular systems [12-14] and solar fuel production in nanostructured and semiconductor based systems [12,15-17], as well as solar energy harvesting utilizing PV cells coupled with electrolysis [18]. The energy harvesting from biomass suffers from losses in the cellular metabolism, and transforming the produced biomass into energy is far from simple. Alternative approaches have been proposed to utilize different microorganisms to generate hydrogen or carbon sources directly from solar energy, but these methods are not yet commercially viable [11]. Artificial photosynthesis and solar fuel production by nanostructured and semiconductor based systems are both rather difficult and requires highly demanding procedures for synthesis of catalysts or for preparation of nanostructured platforms [12,15-17], so scale-up of these systems is even more challenging and the impact of photocatalytic systems has been limited [19]. This clearly demonstrates that alternatives are needed.

Alternative routes for electrochemical solar energy harvesting have been proposed. Chief among these is the photogalvanic approach, where a photoinduced electron transfer reaction occurs in the bulk of an electrolyte solution sandwiched between two electrodes [20,21]. This approach was pioneered by Rabinowitch et al. [22-25] and Albery et al. [20,26-28]. Photogalvanic cells have been recently reviewed by Halls et al. [29]. Briefly, a photoinduced electron transfer reaction occurs not at an electrode but in the bulk of an electrolyte solution between two electrodes to collect the current from the photoproducts. It represents an alternative strategy to photovoltaic cells based on photoelectrochemistry, as in a photogalvanic cell the photochemical reaction is coupled to two classical dark electrochemical reactions. In the case of a reductive quenching, the reduced sensitizer and the oxidized quencher diffuse to the electrodes to be oxidized and reduced, respectively. Here, the recombination is avoided mainly by kinetic factors, setting up concentration gradients. Albery et al. have shown that an optimum efficiency of $18 \%$ is theoretically possible [27], albeit never experimentally achieved with most reported systems operating at an efficiency below $1 \%[20,21]$. Photosystems comprising an aqueous dye, such as thionine $\left(\mathrm{Th}^{+}\right)$, and an aqueous redox quencher, such as Fe(II)

\footnotetext{
* Corresponding author.

E-mail address: pekka.peljo@epfl.ch (P. Peljo).
} 


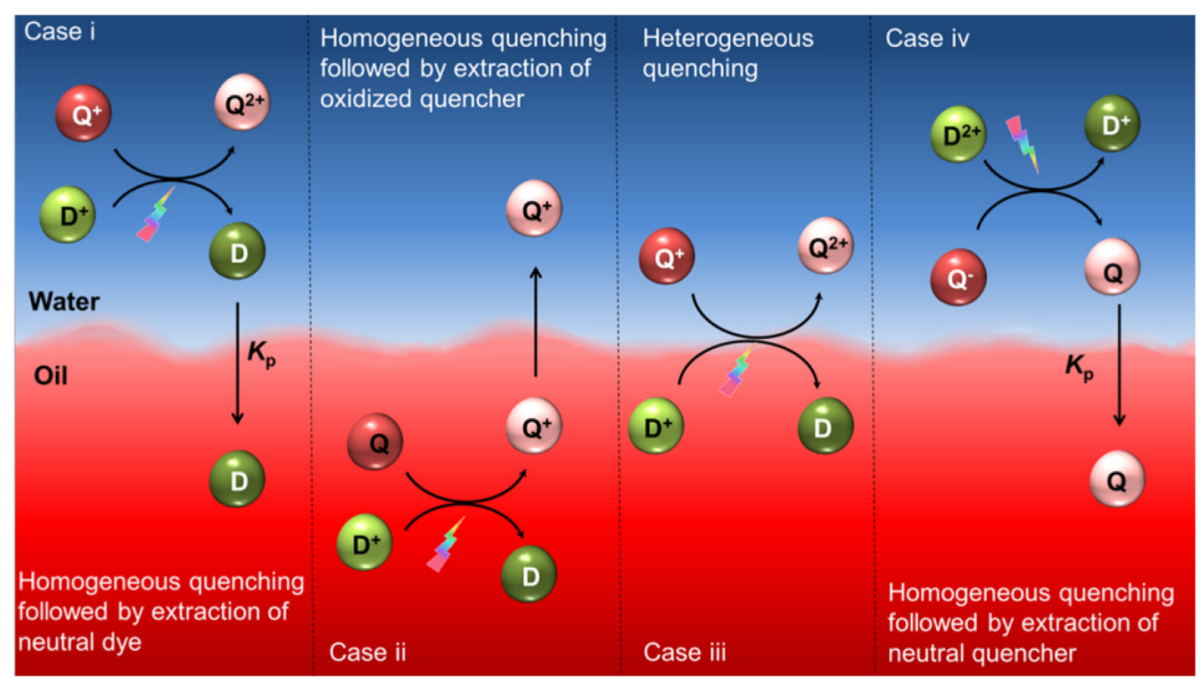

Fig. 1. Possible system configurations for photo-ionic cell. D refers to dye and Q refers to quencher.

have been investigated as early as 1940 as a photogalvanic cell [22,23]. Charge storage has been achieved by precipitation of Fe(III) produced in the photoreaction, or by charge separation at the interface between two immiscible electrolyte solutions. In 1962, Rabinowitch et al. showed that if the photoreaction is carried out in a biphasic water-ether emulsion, the reduced dye is extracted to the organic phase, while the oxidized quencher remains in the aqueous phase [24]. In 1970, the same authors showed that if the aqueous redox quencher is [Co(II) EDTA $]^{2-}$, then a $54 \%$ separation of the photoproducts is possible when working at pH 7.2 [25]. Much of the later work has been focused on using irreversible quenchers, i.e. performing photo-assisted combustion of organic molecules [21,29]. However, this approach is not sustainable, as the system cannot be cycled.

Surfactants can be used to improve the separation of the photoproducts, as shown for example by Grätzel $[30,31]$. In general, photogalvanic systems containing a surfactant produced higher relative values for photocurrent, photopotential, and conversion efficiency than systems without surfactants. Fendler et al. [32] and Atwood et al. [33] have attributed this to the ability of a surfactant to solubilize certain molecules (i.e. the photosensitizing dye) and the catalytic effect that carefully chosen surfactants induce on particular chemical reactions. Furthermore, Rohatgi-Mukherjee et al. theorized that addition of a surfactant into a photogalvanic system increases conversion efficiency via facilitating the separation of photogenerated products by hydrophobic-hydrophilic interaction of the products with the surfactant interface [34]. More recently, Halls et al. have presented a photogalvanic cell based on lyotropic liquid crystal layers entrapping a sensitizer. In this lamellar biphasic approach, a $2 \%$ efficiency was demonstrated [35].

We have recently revisited this concept for solar energy storage, photogalvanic cells, using methodologies developed to study electrochemistry at Interfaces between Two Immiscible Electrolyte Solutions (ITIES) [36,37]. Instead of homogeneous solutions or surfactants, we proposed charge separation by transfer of the photoproducts into adjacent phases, and we have named these systems photo-ionic cells $[38,39]$. Here, the partition of ionic species across the liquid-liquid interface can be controlled electrochemically. The operating principle is that solar energy is converted to redox fuels that are separated into different phases to prevent recombination. The redox fuels can then be converted to electricity when needed, and the process is also producing heat. As the technology does not require complicated manufacturing processes or expensive materials, it could be easy to scale up. We have demonstrated the relevance of polarised ITIES for the charge separation processes for the $\mathrm{Th}^{+}-[\mathrm{Co}(\mathrm{II}) \mathrm{EDTA}]^{2-}$ system. Thanks to the long triplet excited state lifetime of thionine (ca. $20 \mu$ s) and an appreciable partition coefficient of neutral HTh between water and DCE (ca. 15), $86 \%$ of the reduced dye could be extracted in a biphasic system under vigorous stirring [38]. Also, we have optimized the system by exploring other dyes of the phenothiazines family and have reached a quantum yield of $13.8 \%$ (moles of reduced dye produced/moles of photons absorbed) with Azure B as chromophore when utilizing urea as a chaotrope to reduce aggregation of the dyes [39]. We have identified, experimentally and theoretically, the photophysical properties of the chromophores (i.e. molar absorptivity, excited triplet state lifetime, aggregates formation, etc.), the hydrophobicity of the photoproducts, the solubility of the light absorber in the aqueous phase and the potential difference across the interface as the main factors affecting the efficiency of the charge separation [38-40]. To maximize the interfacial surface area available for the transfer of photo-products, dispersion of organic phase into small droplets $[39,40]$ or micro-emulsions has been proposed [41,42]. Recently, amphiphilic mesoporous grapheme was proposed as an efficient material to immobilize dye molecules for photoredox reactions [43]. This approach allows replacement of the organic solvent with a solid material in a system where cationic Azure B dye is trapped by the negatively charged amphiphilic mesoporous grapheme by electrostatic interactions [43]. Dye modified mesoporous graphene was shown to photoreact with Co(II)EDTA, allowing approximately $100 \%$ separation of the reduced dye [43].

Currently, photo-ionic cells with extraction of the neutral dye have been investigated, but other configurations are possible as shown in Fig. 1. In all the cases presented, the Galvani potential difference can be used both to control the partition of ions and to boost the cell voltage, and this has to be taken into account when designing a photo-ionic system.

For conversion of the produced redox fuels into electricity, we have recently proposed a new concept for charge storage in liquid batteries, where the charge is stored as the energy required to transfer a salt (e.g. $\mathrm{LiClO}_{4}$ ) from an aqueous phase into organic phases [44]. The system consists of two organic phases separated by an aqueous electrolyte. Both organic phases contain a redox couple that is almost insoluble in the aqueous phase. Oxidation and reduction of this redox couple is coupled with an ion transfer reaction to maintain the electroneutrality of the phases. The Galvani potential across one interface is controlled by the partition of $\mathrm{Li}^{+}$, at ca. $0.55 \mathrm{~V}$ while the other interface is polarised by $\mathrm{ClO}_{4}{ }^{-}$at ca. $-0.2 \mathrm{~V}$, resulting in secondary battery with a cell voltage of ca. $0.8 \mathrm{~V}$ [44]. The combination of the photo-ionic cell with a fuel cell is shown schematically in Fig. 2.

Photo-ionic systems have nevertheless some serious drawbacks, like 


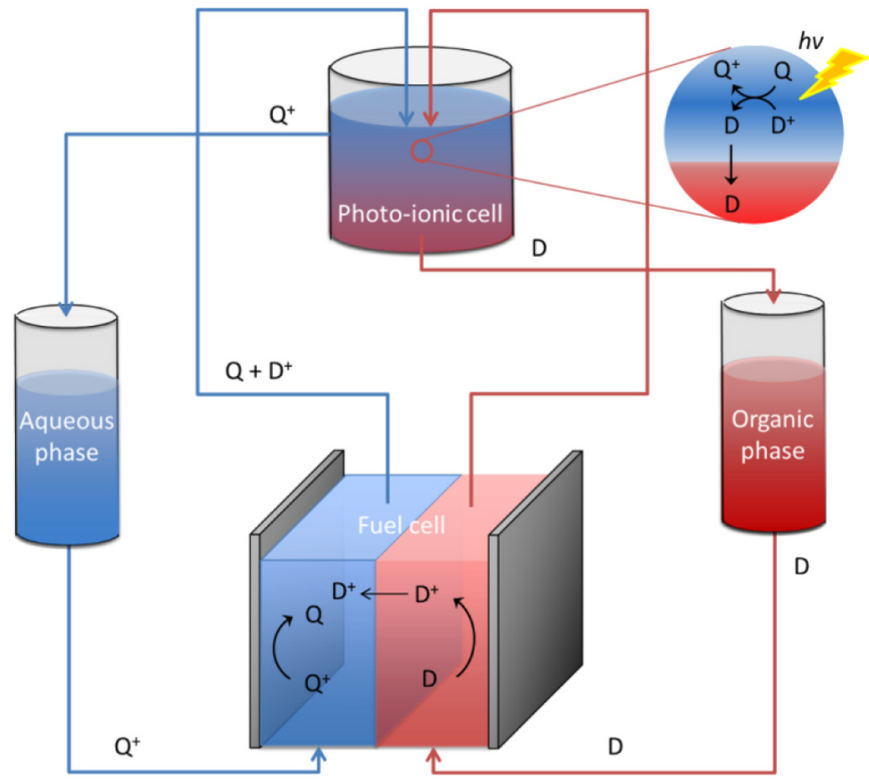

Fig. 2. Solar energy conversion and storage with photo-ionic cell photocharging the redox electrolytes and a fuel cell recovering the energy as electricity.

low potential difference between the two photogenerated redox couples and very low solubility of dyes, which limits the quantum yield of the system. In this work, we investigate the origin of the low potential difference, compare the performance with two organic solvents, 1,2dichloroethane (DCE) and propylene carbonate (PC), and reach an improved cell voltage of up to $0.6 \mathrm{~V}$.

\section{Material and methods}

\subsection{Chemicals}

All aqueous solutions were prepared with ultrapure water (Millipore Milli-Q, specific resistivity $18.2 \mathrm{M} \Omega \cdot \mathrm{cm})$. Azure B chloride $\left(\mathrm{HAzB}^{+} \mathrm{Cl}^{-}\right)$, tetrahexylammonium tetrafluoroborate $\left(\mathrm{THxABF}_{4}, \geq 97.0 \%\right)$, sodium chloride $(\mathrm{NaCl})$, tetrahexylammonium chloride ( $\mathrm{THxACl}, \geq 96.0 \%$ ), propylene carbonate (PC, ReagentPlus ${ }^{\circledR}, 99 \%$ ) were purchased from Sigma-Aldrich. 1,2-dichloroethane (DCE, $\geq 99.8 \%$ ), absolute ethanol $(\geq 99.8 \%)$ and urea $(\geq 99.5 \%)$ were ordered from Acros. They were
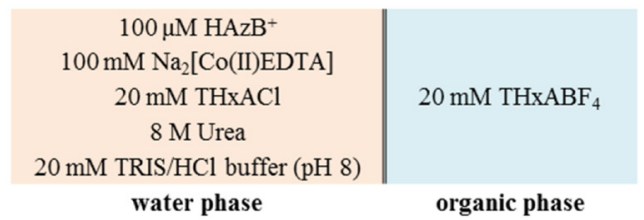
(100-X) $\mu \mathrm{M} \mathrm{HAzB}^{+}$ (100-Y) $\mathrm{mM} \mathrm{Na}_{2}$ [Co(II)EDTA] $\mathrm{Y} \mathrm{mM} \mathrm{Na[Co(III)EDTA]}$ $20 \mathrm{mM}$ THxACl $8 \mathrm{M}$ Urea $20 \mathrm{mM}$ TRIS/ $\mathrm{HCl}$ buffer $(\mathrm{pH} 8)$ water phase
Carbon Felt

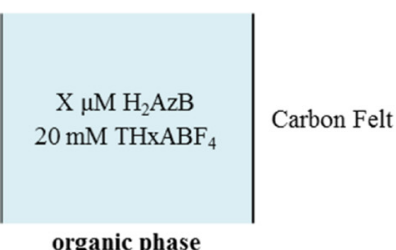

$\sim 100 \mu \mathrm{M} \mathrm{H}_{2} \mathrm{AzB}$ $20 \mathrm{mM} \mathrm{THxABF}_{4} \quad$ Carbon Felt
A

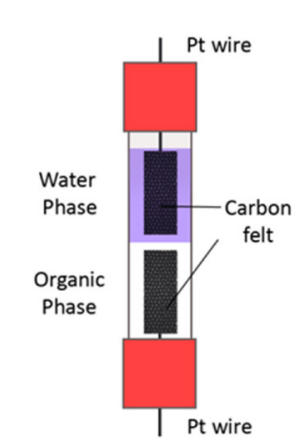

used as received. Sodium cobalt(III) EDTA (Na[Co(III)EDTA]) was synthesized according to the method described by Dwyer et al. [45], whereas the following modification was used for the synthesis of $\mathrm{Na}_{2}$ [Co(II)EDTA]: cobalt(II) acetate (Aldrich, $\geq 99.995 \%$ ), ethylenediaminetetraacetic acid disodium salt $\left(\mathrm{Na}_{2} \mathrm{H}_{2}\right.$ EDTA, Acros), and sodium acetate (Aldrich) were mixed up (1:1:2). Solid $\mathrm{Na}_{2}$ [Co(II)EDTA] was precipitated out of the solution by addition of ethanol, filtered by suction, washed with diethyl ether (Aldrich, $\geq 98.0 \%$ ) and dried under vacuum. Leuco-Azure $B\left(\mathrm{H}_{2} \mathrm{AzB}\right)$ was synthesized via a potential-controlled bulk electrolysis at $-0.55 \mathrm{~V}$ vs $\mathrm{Ag} / \mathrm{AgCl}(3 \mathrm{M} \mathrm{KCl})$ at $\mathrm{pH} 8.0$ in an $\mathrm{H}$-Cell with two high surface area vitreous carbon electrodes from a solution of Azure B in a $20 \mathrm{mM}$ Tris buffer. For a pH range from 7.5 to 9.0, tris(hydroxymethyl)aminomethane (Tris, Acros Organics, $\geq 99.8 \%$ ) was used with hydrochloric acid (Acros Organics, $32 \%$ solution in water) for $\mathrm{pH}$ adjustments.

\subsection{Photo-extraction and electrochemical experiments}

For all electrochemical measurements, a PGSTAT 30 potentiostat (Metrohm, CH) was used. All measurements were conducted in a nitrogen filled glove box and all solutions and solvents were carefully deoxygenated before usage. As electrodes for measurements in the twoelectrode cell, we used carbon felt (SGL Carbon) with platinum wire connection. Scheme 1 presents the configuration of the cells studied in this work. DCE or PC was used as the organic phases. Azure B was chosen as a model dye to compare these two solvents. In case of PC, $1 \mathrm{M}$ $\mathrm{NaCl}$ was added to the water phase to stabilize the interface, and water phase was saturated with PC. pH of the solution was chosen based on earlier optimization [39].

For photoreaction experiments, equal volumes of aqueous and organic phases (Scheme 1A) were irradiated with a red LED light (Thorlabs, $1234 \mathrm{~W} \cdot \mathrm{m}^{-2}$ at $625 \mathrm{~nm}$ ) under vigorous stirring until the photoreaction occurred. To measure the cell voltage, a two-electrode cell presented on the Scheme 1 was used. After photocharging, the phases were quickly separated and transferred into the electrochemical cell to measure the open circuit voltage as well as to carry out voltammetry investigations (Scheme 1B). Chemically prepared $\mathrm{Na}[\mathrm{Co}(\mathrm{III}) \mathrm{EDTA}]$ and leuco-Azure B prepared by bulk electrolysis were used to measure the open circuit voltage and the voltammetric response for the fully charged cell (Scheme 1C). High surface area carbon felt electrodes were required to overcome the slow kinetics of the $\mathrm{Co}(\mathrm{III}) / \mathrm{Co}(\mathrm{II})$ couple. Studied solutions were prepared likewise as for the voltage measurement experiments.
$100 \mathrm{mM} \mathrm{Na}[\mathrm{Co}$ (III)EDTA] $\mathrm{mM}$ THxAC

$20 \mathrm{mM}$ TRIS/HCl buffer ( $\mathrm{pH} 8$ ) water phase organic phase
Scheme 1. Cell configurations for (A) cell for the red LED activated charging of the photo-ionic cell, (B) discharge of the cell presented in (A) after irradiation, and (C) discharge of the chemically prepared photoproducts. In case of PC, $1 \mathrm{M} \mathrm{NaCl}$ was added to the water phase saturated with propylene carbonate. The two-electrode cell for voltage and voltammetry measurements is shown on the right. 


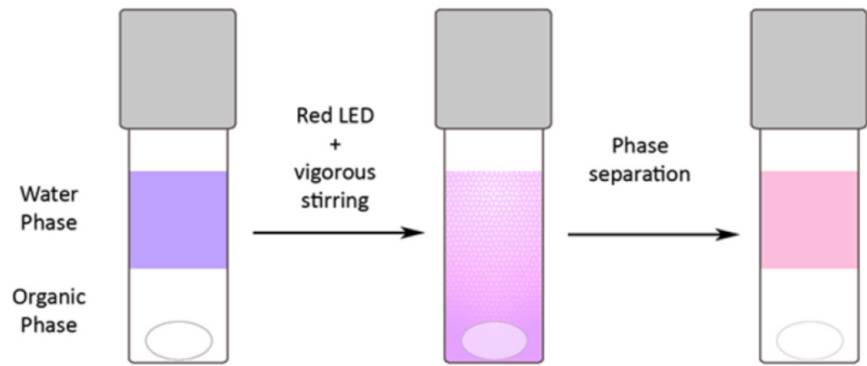

Fig. 3. Quartz cell for spectroscopic measurements of kinetics.

\subsection{Spectroscopic measurements}

An Agilent 8452 spectrophotometer was used for all the spectroscopic measurements. To evaluate the dimerization constants of Azure $B$ in different solutions, a quartz cell with $0.1 \mathrm{~cm}$ path length, filled in the glove box under nitrogen, was utilized. All aqueous solutions were fully saturated with PC, and PC solutions were fully saturated with water. For kinetics measurements, a quartz cell with $1 \mathrm{~cm}$ path length was used to enable stirring of the solution. As the absorption of $100 \mu \mathrm{M}$ $\mathrm{HazB}^{+}$would be too high for this path length, $50 \mu \mathrm{M} \mathrm{HazB}{ }^{+}$with $50 \mathrm{mM} \mathrm{Na}_{2}$ [Co(II)EDTA] was used instead while the concentration of the rest of the components was as described in cell A of the Scheme 1. The cuvette was filled with equal amounts of aqueous and organic phases under inert atmosphere, and closed with the rubber septa cap to prevent the effects with oxygen (Fig. 3). The cuvette was irradiated with a red LED light (Thorlabs, $1234 \mathrm{~W} \cdot \mathrm{m}^{-2}$ at $625 \mathrm{~nm}$ ) under vigorous stirring for a certain amount of time, and after phase separation absorbance in the water phase at $651 \mathrm{~nm}$ was measured.

The partition coefficient of the reduced Azure B was determined by evaluating the change in the absorbance of the leuco-Azure $B$ $(\lambda=255 \mathrm{~nm})$ synthesized by bulk electrolysis in the aqueous phase after equilibration with an equal amount of organic phase [39]. The partition coefficient for $\mathrm{HAzB}^{+}(\lambda=650 \mathrm{~nm})$ was determined likewise.

\section{Theory}

\subsection{Cell voltage}

The voltage of the cell described in Scheme 2, defined as the Galvani potential difference between the two copper wires, can be calculated from the differences of Galvani potentials at each junction

$$
\begin{aligned}
E= & \phi^{\mathrm{Cu}^{\prime}}-\phi^{\mathrm{Cu}}=\left(\phi^{\mathrm{Cu}^{\prime}}-\phi^{\text {graphite }}\right)+\left(\phi^{\text {graphite }}-\phi^{\mathrm{w}}\right)+\left(\phi^{\mathrm{w}}-\phi^{\mathrm{o}}\right) \\
& +\left(\phi^{\mathrm{o}}-\phi^{\text {graphite }}\right)+\left(\phi^{\text {graphite }}-\phi^{\mathrm{Cu}}\right)
\end{aligned}
$$

Between the $\mathrm{Cu}$ wire and the graphite electrode, the electrons are in equilibrium with each other, and we can write the equality of the electrochemical potential $\tilde{\mu}_{i}$ :

$\widetilde{\mu}_{e^{-}}^{\mathrm{Cu}}=\tilde{\mu}_{e^{-}}^{\text {graphite }}$

For the graphite electrode in contact with the organic phase the equilibrium redox reaction is $\mathrm{D}^{+}+e^{-} \rightleftharpoons \mathrm{D}$, so

$\widetilde{\mu}_{\mathrm{D}}^{\mathrm{o}}=\widetilde{\mu}_{\mathrm{D}^{+}}^{\mathrm{o}}+\widetilde{\mu}_{e^{-}}^{\text {graphite }}$

For the graphite electrode in contact with the aqueous phase the equilibrium redox reaction is $\mathrm{Q}^{+}+e^{-} \rightleftharpoons \mathrm{Q}$, so

$$
\underset{\mathrm{O}}{\mathrm{Cu} \mid} \underset{\mathrm{w}}{\text { graphite }}\left|\mathrm{D}^{+}, \mathrm{D}, \mathrm{C}^{+}, \mathrm{A}_{\mathrm{o}}{ }^{-}\right| \mathrm{Q}^{+}, \mathrm{Q}, \mathrm{C}^{+}, \mathrm{A}_{\mathrm{w}}{ }^{-} \mid \text {graphite' } \mid \mathrm{Cu} \text { ' }
$$

Scheme 2. Electrochemical cell, where the Galvani potential difference across the water-oil interface is controlled by the partition of a common ion $\mathrm{C}^{+}$.
$\tilde{\mu}_{\mathrm{Q}}^{\mathrm{w}}=\tilde{\mu}_{\mathrm{Q}^{+}}^{\mathrm{w}}+\tilde{\mu}_{e^{-}}^{\text {graphite }^{\prime}}$

Lastly, the electrons are in equilibrium between $\mathrm{Cu}^{\prime}$ wire and graphite' electrode:

$\widetilde{\mu}_{e^{-}}^{\mathrm{Cu}^{\prime}}=\widetilde{\mu}_{e^{-}}^{\text {graphite' }}$

By utilizing the definition of the electrochemical potential of species $i$ in phase $\alpha$ :

$\tilde{\mu}_{i}^{\alpha}=\mu_{i}^{\alpha}+z_{i} F \phi^{\alpha}$

where $\mu_{i}^{\alpha}$ is the chemical potential of species $i$ in phase $\alpha, z_{i}$ is the charge of species $i$ and $\phi^{\alpha}$ is the Galvani potential of the phase $\alpha$, we can rewrite Eqs. (2)-(6) as:

$F\left(\phi^{\mathrm{Cu}^{\prime}}-\phi^{\text {graphite' }}\right)=\mu_{e^{-}}^{\mathrm{Cu}^{\prime}}-\mu_{e^{-}}^{\text {graphite }}$

$F\left(\phi^{\text {graphite }}-\phi^{\mathrm{w}}\right)=\mu_{\mathrm{Q}^{+}}^{\mathrm{w}}+\mu_{e^{-}}^{\text {graphite }^{\prime}}-\mu_{\mathrm{Q}}^{\mathrm{w}}$

$F\left(\phi^{\mathrm{o}}-\phi^{\text {graphite }}\right)=\mu_{\mathrm{D}}^{\mathrm{o}}-\mu_{\mathrm{D}^{+}}^{\mathrm{o}}-\mu_{e^{-}}^{\text {graphite }}$

$F\left(\phi^{\text {graphite }}-\phi^{\mathrm{Cu}}\right)=\mu_{e^{\text {graphite }}}-\mu_{e^{-}}^{\mathrm{Cu}}$

Now the expressions in Eq. (8) can be substituted into Eq. (1) to obtain the expression for cell voltage

$$
\begin{aligned}
F E= & \mu_{e^{-}}^{\mathrm{Cu}^{\prime}}-\mu_{e^{-}}^{\text {graphite }^{\prime}}+\mu_{\mathrm{Q}^{+}}^{\mathrm{w}}+\mu_{e^{-}}^{\text {graphite }^{\prime}}-\mu_{\mathrm{Q}}^{\mathrm{w}}+F\left(\phi^{\mathrm{w}}-\phi^{\mathrm{o}}\right)+\mu_{\mathrm{D}}^{\mathrm{o}}-\mu_{\mathrm{D}^{+}}^{\mathrm{o}} \\
& -\mu_{e^{-}}^{\text {graphite }}+\mu_{e^{-}}^{\text {graphite }}-\mu_{e^{-}}^{\mathrm{Cu}}
\end{aligned}
$$

that simplifies to give

$F E=\mu_{\mathrm{Q}^{+}}^{\mathrm{w}}-\mu_{\mathrm{Q}}^{\mathrm{w}}+F\left(\phi^{\mathrm{w}}-\phi^{\mathrm{o}}\right)+\mu_{\mathrm{D}}^{\mathrm{o}}-\mu_{\mathrm{D}^{+}}^{\mathrm{o}}$

because the chemical potential of electrons is the same in $\mathrm{Cu}$ and $\mathrm{Cu}^{\prime}$. Finally, the chemical potential of a species $i$ can be expressed as

$\mu_{i}=\mu_{i}^{0-}+R T \ln a_{i}$

where $\mu_{i}^{0-}$ is the standard chemical potential, $R$ and $T$ are the gas constant and temperature, respectively, and $a_{i}$ is the activity of the species $i$. Substitution of Eq. (10) into Eq. (9) results in

$$
\begin{aligned}
E= & \frac{\mu_{\mathrm{Q}^{+}}^{\mathrm{o}-\mathrm{w}}-\mu_{\mathrm{Q}}^{\mathrm{o}-, \mathrm{w}}}{F}+\frac{R T}{F} \ln \frac{a_{\mathrm{Q}^{+}}^{\mathrm{w}}}{a_{\mathrm{Q}}^{\mathrm{w}}}+\left(\phi^{\mathrm{w}}-\phi^{\mathrm{o}}\right)+\frac{\mu_{\mathrm{D}}^{\mathrm{o}-, \mathrm{o}}-\mu_{\mathrm{D}^{+}}^{\mathrm{o}-, \mathrm{o}}}{F} \\
& -\frac{R T}{F} \ln \frac{a_{\mathrm{D}^{+}}^{\mathrm{o}}}{a_{\mathrm{D}}^{\mathrm{o}}}
\end{aligned}
$$

By utilizing the definition of the standard redox potential versus the standard hydrogen electrode (SHE) in any solvent S [46]:

$\left[E_{\mathrm{ox} / \mathrm{red}}^{\mathrm{o}-}\right]_{\mathrm{SHE}}=\frac{\mu_{\mathrm{ox}}^{\mathrm{o}-, \mathrm{S}}-\mu_{\mathrm{red}}^{\mathrm{o}-, \mathrm{S}}-\mu_{\mathrm{H}^{+}}^{\mathrm{o}-, \mathrm{w}}+\frac{1}{2} \mu_{\mathrm{H}_{2}}^{\mathrm{o}-}}{F}$

we can modify Eq. (11) as

$$
\begin{aligned}
E= & {\left[\frac{\mu_{\mathrm{Q}^{+}}^{\mathrm{o}-\mathrm{w}}-\mu_{\mathrm{Q}}^{\mathrm{o}-, \mathrm{w}}-\mu_{\mathrm{H}^{+}}^{\mathrm{o}-\mathrm{w}}+\frac{1}{2} \mu_{\mathrm{H}_{2}}^{\mathrm{o}-}}{F}+\frac{R T}{F} \ln \frac{a_{\mathrm{Q}^{+}}^{\mathrm{w}}}{a_{\mathrm{Q}}^{\mathrm{w}}}\right]+\left(\phi^{\mathrm{w}}-\phi^{\mathrm{o}}\right) } \\
& -\left[\frac{\mu_{\mathrm{D}^{+}}^{\mathrm{o}-\mathrm{o}}-\mu_{\mathrm{D}}^{\mathrm{o}-, \mathrm{o}}-\mu_{\mathrm{H}^{+}}^{\mathrm{o}-\mathrm{w}}+\frac{1}{2} \mu_{\mathrm{H}_{2}}^{\mathrm{o}-}}{F}-\frac{R T}{F} \ln \frac{a_{\mathrm{D}^{+}}^{\mathrm{o}}}{a_{\mathrm{D}}^{\mathrm{o}}}\right]
\end{aligned}
$$

$$
\begin{aligned}
E= & \left(\left[E_{\mathrm{Q}^{+} / \mathrm{Q}}^{\mathrm{o}}\right]_{\mathrm{SHE}}^{\mathrm{w}}+\frac{R T}{F} \ln \frac{a_{\mathrm{Q}^{+}}^{\mathrm{w}}}{a_{\mathrm{Q}}^{\mathrm{w}}}\right)+\left(\phi^{\mathrm{w}}-\phi^{\mathrm{o}}\right) \\
& -\left(\left[E_{\mathrm{D}^{+} / \mathrm{D}}^{\mathrm{o}}\right]_{\mathrm{SHE}}^{\mathrm{o}}+\frac{R T}{F} \ln \frac{a_{\mathrm{D}^{+}}^{\mathrm{o}}}{a_{\mathrm{D}}^{\mathrm{o}}}\right)
\end{aligned}
$$

The terms in brackets are the Nernst potentials of $\mathrm{Q}^{+} / \mathrm{Q}$ and $\mathrm{D}^{+} / \mathrm{D}$ redox couples in their respective phases $\mathrm{w}$ and $\mathrm{o}$. The Galvani potential difference for the liquid-liquid interface is given by the Nernst equation for the partitioning ion $i$ [46]. 
$\left(\phi^{\mathrm{w}}-\phi^{\mathrm{o}}\right)=\Delta_{\mathrm{o}}^{\mathrm{w}} \phi=\Delta_{\mathrm{o}}^{\mathrm{w}} \phi_{i}^{\mathrm{o}-}+\frac{R T}{z_{i} F} \ln \frac{a_{i}^{\mathrm{o}}}{a_{i}^{\mathrm{w}}}$

where $\Delta_{\mathrm{o}}^{\mathrm{w}} \phi_{i}^{\mathrm{o}-}$ is the standard transfer potential of $i$ and $a_{i}{ }^{\mathrm{o}}$ and $a_{i}^{\mathrm{w}}$ are the activities of $i$ in aqueous and organic phases and $z_{i}$ is the charge of $i$. The standard transfer potential is connected to the standard Gibbs energy of transfer of the ion $i$ from the aqueous to the organic phase by the following expression [46]:

$\Delta_{\mathrm{o}}^{\mathrm{w}} \phi_{i}^{\mathrm{o}-}=\frac{\Delta G_{\mathrm{tr}, i}^{\mathrm{o}, \mathrm{w} \rightarrow \mathrm{o}}}{z_{i} F}$

In more rigorous treatment, the effect of all the species percent in the system should be taken into account when calculating the equilibrium distribution and the Galvani potential difference [47], but this effect can be omitted if one partitioning ion is in excess over other species.

In Scheme 2, both phases contain a common cation $\mathrm{C}^{+}$, so Eq. (14) can be written as

$$
\begin{aligned}
E= & \left(\left[E_{\mathrm{Q}^{+} / \mathrm{Q}}^{\mathrm{o}}\right]_{\mathrm{SHE}}^{\mathrm{w}}+\frac{R T}{F} \ln \frac{a_{\mathrm{Q}^{+}}}{a_{\mathrm{Q}}}\right)+\left(\Delta_{\mathrm{o}}^{\mathrm{w}} \phi_{\mathrm{C}^{+}}^{\mathrm{o}}+\frac{R T}{F} \ln \frac{a_{\mathrm{C}^{+}}^{\mathrm{o}}}{a_{\mathrm{C}^{+}}^{\mathrm{w}}}\right) \\
& -\left(\left[E_{\mathrm{D}^{+} / \mathrm{D}}^{\mathrm{o}}\right]_{\mathrm{SHE}}^{\mathrm{o}}+\frac{R T}{F} \ln \frac{a_{\mathrm{D}^{+}}}{a_{\mathrm{D}}}\right)
\end{aligned}
$$

To switch from activities to concentrations, standard potentials can be replaced by the formal potentials (as signified by the superscript ') that are more readily measurable:

$$
\begin{aligned}
E= & \left(\left[E_{\mathrm{Q}^{+}, \mathrm{Q}_{\mathrm{S}}^{\mathrm{o}},}^{\mathrm{w}}\right]_{\mathrm{SH}}^{\mathrm{w}}+\frac{R T}{F} \ln \frac{c_{\mathrm{Q}^{+}}}{c_{\mathrm{Q}}}\right)+\left(\Delta_{\mathrm{O}}^{\mathrm{w}} \phi_{\mathrm{C}^{+}}^{\mathrm{o}-,}+\frac{R T}{F} \ln \frac{c_{\mathrm{C}^{+}}^{\mathrm{o}}}{c_{\mathrm{C}^{+}}^{\mathrm{w}}}\right) \\
& -\left(\left[E_{\mathrm{D}^{+} / \mathrm{D}}^{\mathrm{o}-,}\right]_{\mathrm{SHE}}^{\mathrm{o}}+\frac{R T}{F} \ln \frac{c_{\mathrm{D}^{+}}}{c_{\mathrm{D}}}\right)
\end{aligned}
$$

This expression can be simplified as

$E=E_{a q}-E_{o i l}+\Delta_{\mathrm{o}}^{\mathrm{w}} \phi$

where $E_{a q}$ and $E_{\text {oil }}$ are the Nernst potentials of the $\mathrm{Q}^{+} / \mathrm{Q}$ couple in aqueous phase and $\mathrm{D}^{+} / \mathrm{D}$ couple in the organic phase.

\subsection{Redox potentials in non-aqueous phases}

The derivation of the standard potential of ox/red couple in a nonaqueous solvent vs. the standard hydrogen electrode has been described before $[46,48,49]$, but is recalled here as it represents a key concept in biphasic systems. For a redox reaction

$\mathrm{O}_{\mathrm{x}}(\mathrm{o})+n e^{-} \rightleftharpoons \operatorname{Red}(\mathrm{o}) \quad\left[E_{\mathrm{Ox} / \operatorname{Red}}^{\mathrm{o}}\right]_{\mathrm{SHE}}^{\mathrm{o}}$

where species Ox and Red are present in oil phase o. The standard potential in the oil phase and in water on the SHE scale can be expressed as $[46,48,49]$ :

$\left[E_{\mathrm{Ox} / \mathrm{Red}}^{\mathrm{o}-}\right]_{\mathrm{SHE}}^{\mathrm{o}}=\frac{1}{n F}\left[\left(\mu_{\mathrm{Ox}}^{\mathrm{o}-, \mathrm{o}}-\mu_{\mathrm{Red}}^{\mathrm{o}-\mathrm{o}}\right)-n\left(\mu_{\mathrm{H}^{+}}^{\mathrm{o}-\mathrm{w}}-\frac{1}{2} \mu_{\mathrm{H}_{2}}^{\mathrm{o}-}\right)\right]$

$\left[E_{\mathrm{OX} / \mathrm{Red}}^{\mathrm{o}-}\right]_{\mathrm{SHE}}^{\mathrm{w}}=\frac{1}{n F}\left[\left(\mu_{\mathrm{Ox}}^{\mathrm{o}-\mathrm{w}}-\mu_{\mathrm{Red}}^{\mathrm{o}-, \mathrm{w}}\right)-n\left(\mu_{\mathrm{H}^{+}}^{\mathrm{o}-\mathrm{w}}-\frac{1}{2} \mu_{\mathrm{H}_{2}}^{\mathrm{o}-}\right)\right]$

Combination of these two equations results in:

$\left[E_{\mathrm{Ox} / \mathrm{Red}}^{\mathrm{o}-}\right]_{\mathrm{SHE}}^{\mathrm{o}}=\left[E_{\mathrm{Ox} / \mathrm{Red}}^{\mathrm{o}-}\right]_{\mathrm{SHE}}^{\mathrm{W}}+\frac{1}{n F}\left[\left(\mu_{\mathrm{Ox}}^{\mathrm{o}-, \mathrm{o}}-\mu_{\mathrm{Red}}^{\mathrm{o}-, \mathrm{o}}\right)-n\left(\mu_{\mathrm{H}^{+}}^{\mathrm{o}-\mathrm{w}}-\frac{1}{2} \mu_{\mathrm{H}_{2}}^{\mathrm{o}-}\right)\right]$

$-\frac{1}{n F}\left[\left(\mu_{\mathrm{Ox}}^{\mathrm{o}-, \mathrm{w}}-\mu_{\mathrm{Red}}^{\mathrm{o}-\mathrm{w}}\right)-n\left(\mu_{\mathrm{H}^{+}}^{\mathrm{o}-\mathrm{w}}-\frac{1}{2} \mu_{\mathrm{H}_{2}}^{\mathrm{o}-}\right)\right]$

$\left[E_{\mathrm{Ox} / \mathrm{Red}}^{\mathrm{o}-}\right]_{\mathrm{SHE}}^{\mathrm{o}}=\left[E_{\mathrm{Ox} / \mathrm{Red}}^{\mathrm{o}-}\right]_{\mathrm{SHE}}^{\mathrm{W}}+\frac{1}{n F}\left[\left(\mu_{\mathrm{Ox}}^{\mathrm{o}-, \mathrm{o}}-\mu_{\mathrm{Ox}}^{\mathrm{o}-, \mathrm{w}}\right)-\left(\mu_{\mathrm{Red}}^{\mathrm{o}-, \mathrm{o}}-\mu_{\mathrm{Red}}^{\mathrm{o}-\mathrm{w}}\right)\right]$

As the standard Gibbs energy of transfer of a species $i$ from aqueous phase into oil phase is

$\Delta G_{\mathrm{tr}, i}^{\mathrm{o}-, \mathrm{w} \rightarrow \mathrm{o}}=\mu_{i}^{\mathrm{o}-, \mathrm{o}}-\mu_{i}^{\mathrm{o}-, \mathrm{w}}$

Eq. (24) can be written as

$\left[E_{\mathrm{Ox} / \mathrm{Red}}^{\mathrm{o}-}\right]_{\mathrm{SHE}}^{\mathrm{o}}=\left[E_{\mathrm{Ox} / \mathrm{Red}}^{\mathrm{o}-}\right]_{\mathrm{SHE}}^{\mathrm{W}}+\frac{1}{n F}\left[\Delta G_{\mathrm{tr}, \mathrm{Ox}}^{\mathrm{o}-, \mathrm{W} \rightarrow \mathrm{o}}-\Delta G_{\mathrm{tr}, \operatorname{Red}}^{\mathrm{o}-\mathrm{w} \rightarrow \mathrm{o}}\right]$

Eq. (26) is equal to the thermodynamic cycle where Red is transferred from o to $\mathrm{w}$, oxidized in the aqueous phase to Ox and finally the Ox is transferred into the oil phase o. If species $i$ is neutral the standard Gibbs energy of transfer can be calculated if the partition coefficient $K$ of the species $i$ is known:

$\Delta G_{\mathrm{tr}, i(z=0)}^{\mathrm{o}-, \mathrm{w} \rightarrow \mathrm{o}}=-R T \ln K, \quad K=\frac{c_{i}^{\mathrm{o}}}{c_{i}^{\mathrm{w}}}$

If species $i$ is charged the standard Gibbs energy of transfer can be calculated from Eq. (16):

$\Delta G_{\mathrm{tr}, i(z \neq 0)}^{\mathrm{o}-, \mathrm{w} \rightarrow \mathrm{o}}=z_{i} F \Delta_{\mathrm{o}}^{\mathrm{w}} \phi_{i}^{\mathrm{o}-}$

For example, the standard potential of the $\mathrm{HAzB}^{+} / \mathrm{H}_{2} \mathrm{AzB}$ in an organic phase $o$ can be calculated as follows. The redox reaction is:

$\mathrm{HAzB}^{+}+2 e^{-}+\mathrm{H}^{+} \rightleftharpoons \mathrm{H}_{2} \mathrm{AzB}$

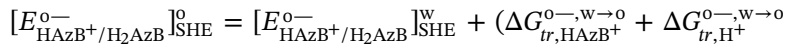

$$
\left.-\Delta G_{t r, \mathrm{H}_{2} \mathrm{AzB}}^{\mathrm{O}-\mathrm{W} \rightarrow \mathrm{O}}\right) / 2 F
$$

Indeed, the Gibbs energy of transfer of the protons has also to be

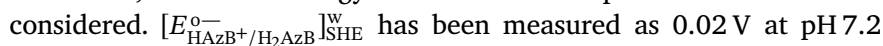
[39]. The standard transfer energy $\mathrm{HAzB}^{+}$is calculated with Eq. (28) when the standard transfer potential of $\mathrm{HAzB}^{+}$is known $\left(\Delta_{\mathrm{DCE}}^{\mathrm{w}} \phi_{\mathrm{HAzB}^{+}}^{\mathrm{o}-}=-0.19 \mathrm{~V}\right.$ [39], i.e. $\left.\Delta G_{\mathrm{tr}, \mathrm{HAzB}}^{\mathrm{o}-\mathrm{wCE}}=-18.3 \mathrm{~kJ} \mathrm{~mol}^{-1}\right)$. The standard transfer energy of the neutral $\mathrm{H}_{2} \mathrm{AzB}$ can be calculated with Eq. (27), when the partition coefficient of $\mathrm{H}_{2} \mathrm{AzB}$ is known (Table 2, resulting in $\Delta G_{\mathrm{tr}, \mathrm{H}_{2} \mathrm{AzB}}^{\mathrm{O}-\mathrm{W} \rightarrow \mathrm{DCE}}=-4.4$ or $-3.7 \mathrm{~kJ} \cdot \mathrm{mol}^{-1}$, without and with urea, respectively). Finally, the standard transfer energy of protons is known from the literature $\left(\Delta G_{\mathrm{tr}, \mathrm{H}^{+}}^{\mathrm{o}-\mathrm{wCE}}=53 \mathrm{~kJ} \cdot \mathrm{mol}^{-1}\right.$ [50], while the value in the presence of $8 \mathrm{M}$ urea is slightly less). With this data, the final result is $\left.\left[E_{\mathrm{HAzB}^{+} / \mathrm{H}_{2} \mathrm{AzB}}^{\mathrm{O}}\right]\right]_{\mathrm{SHE}}^{\mathrm{DCE}}=0.22 \mathrm{~V}$. For wet propylene carbonate, the transfer energy of protons $\Delta G_{\mathrm{tr}, \mathrm{H}^{+}}^{\mathrm{o}-\mathrm{wC} \rightarrow \mathrm{PC}}$ can be considered negligible. If this value

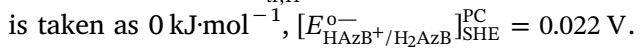

\section{Results and discussion}

We can now apply Eq. (19) to the Azure B-Co(EDTA) system. The formal potential of the aqueous [Co(III)EDTA $]^{2-} /[\mathrm{Co}(\mathrm{II}) \mathrm{EDTA}]^{-}$couple is $0.37-0.38 \mathrm{~V}$ vs. SHE $[51,52]$, while the formal potential of the Azure $\mathrm{B} /$ leuco-Azure B couple ( $\mathrm{HAzB}^{+} / \mathrm{H}_{2} \mathrm{AzB}$ ) in DCE can be estimated as $0.22 \mathrm{~V}$, as detailed in Section 3.2. $\mathrm{THxA}^{+}$cation with a standard ion transfer potential of $-0.46 \mathrm{~V}$ [53] is used to polarise the interface. If we consider a system where the concentration ratio of $\mathrm{Q}^{+} / \mathrm{Q}$ and $\mathrm{D}^{+} / \mathrm{D}$ are $1: 1$, and where the amount of $\mathrm{THxA}^{+}$in the aqueous and organic phases is also equal, the expected cell voltage can be calculated by Eq. (19), resulting in $E=E_{a q}-E_{\text {oil }}+\Delta_{\mathrm{o}}{ }^{\mathrm{w}} \phi \approx 0.4 \mathrm{~V}-0.2+(-0.4 \mathrm{~V})=-0.2 \mathrm{~V}$.

In fact, also the effect of other species on the Galvani potential should be considered, as the situation is dynamic and interfacial concentrations change over time. The equilibrium concentrations can be calculated as detailed for example in ref. [47], with the standard transfer energies taken from the LEPA database (http://sbsrv7.epfl.ch/ instituts/isic/lepa/cgi/DB/InterrDB.pl). Examples are available for example in refs. [49,54]. The transfer potentials of CoEDTA species were assumed to be $-0.7 \mathrm{~V}$ as they are beyond the negative end of the potential window. If we consider cell A in Scheme 1, the shift from the standard ion transfer potential of $\mathrm{THxA}^{+}$is only $+2.9 \mathrm{mV}$, and after the reaction in the fuel cell, where reduction of [Co(III)EDTA $]^{-}$in the aqueous phase and oxidation of $\mathrm{H}_{2} \mathrm{AzB}$ in the organic phase is 
accompanied by the transfer of stoichiometric amount of $\mathrm{THxA}^{+}$from the organic to the aqueous phase, the shift is still only $+2.6 \mathrm{mV}$. However, if the ratio of $\mathrm{THxA}+$ to $\mathrm{HAzB}^{+}$is adjusted, these changes can become more significant. For example, consideration of cell A with $5 \mathrm{mM}$ Azure B results in $+3.5 \mathrm{mV}$ in equilibrium, and for $-15 \mathrm{mV}$ shift after the reaction in the fuel cell.

Basically, all the photogenerated voltage is required to overcome the negative Galvani potential difference required to keep the Azure B in the aqueous phase. Additionally, the Nernst potentials of both [Co (III)EDTA $]^{2-} /[\mathrm{Co}(\mathrm{II}) E D T A]^{-}$couple and $\mathrm{HAzB}^{+} / \mathrm{H}_{2} \mathrm{AzB}$ change by ca. $60 / n \mathrm{mV}$ per decade of change in the ratio of oxidized and reduced species, where $n$ is the number of electrons in the redox reaction $(n=1$ for $[\mathrm{Co}(\mathrm{III}) \mathrm{EDTA}]^{2-} /[\mathrm{Co}(\mathrm{II}) \mathrm{EDTA}]^{-}$and $n=2$ for $\mathrm{HAzB}^{+} / \mathrm{H}_{2} \mathrm{AzB}$ couple). For example, the Nernst potential of the organic phase of a fully charged cell with $\mathrm{HAzB}^{+} / \mathrm{H}_{2} \mathrm{AzB}$ ratio of $1: 100$ would be $60 \mathrm{mV}$ more negative than the formal potential $(n=2)$, while the Nernst potential of the aqueous phase of a fully charged cell with $\mathrm{Co}(\mathrm{III}) / \mathrm{Co}(\mathrm{II})$ ratio of 100:1 would be $120 \mathrm{mV}$ more positive than the formal potential. In this case the expected cell voltage would be close to $0 \mathrm{~V}$. This indicates that the photo-ionic cell should be designed to take advantage of the applied Galvani potential difference. This is highlighted in Fig. 4, showing the effect of the Galvani potential on the cell voltage. Herein, we consider a hypothetical system with the standard potential of the dye in the organic phase $\left[E_{\mathrm{D}^{+} / \mathrm{D}}^{\mathrm{o}}\right]_{\mathrm{SHE}}^{0}=0 \mathrm{~V}$ and the standard potential of the quencher in the aqueous phase $\left[E_{\mathrm{Q}^{+} / \mathrm{Q}}^{\mathrm{o}}\right]_{\mathrm{SHE}}^{\mathrm{W}}=0.4 \mathrm{~V}$.

Another option developed here is to choose a system where $\Delta_{\mathrm{o}}{ }^{\mathrm{w}} \phi$ is not significant, i.e. a system where the solvation energies of the partitioning ion are very similar, such as for water and propylene carbonate. Indeed, mutually saturated water and propylene carbonate solvate ions very similarly, and the water-PC interface cannot polarised. In this case, the cell voltage will be reduced to $E=E_{a q}-E_{\text {oil }}$.

\subsection{Dye dimerization}

Aggregation of the dye is an unwanted process because aggregates have lower life-times of excited states [39]. Hence, the formation of dimers affects quantum yields adversely. It is well-known that aggregation of molecules is affected by the presence of chaotropic or chalcotropic agents [55]. Chaotropic agents can break the structure of the water and weaken the hydrophobic effect, reducing the aggregation of hydrophobic molecules in water $[56,57]$. Urea has previously been used as a chaotrope to reduce the aggregation of dyes in photo-ionic cells, enabling higher solubility of dyes and an order of magnitude higher quantum yield of ca. 13\% [39]. In comparison with DCE, PC is much more soluble in water. As a result, it is much harder to form an interface between these two phases. To stabilize this interface, saltingout agents such as $1 \mathrm{M} \mathrm{NaCl}$ can be used to force the separation of PC and water rich phases. In this work, all aqueous solutions were saturated with PC $\left(T=20-25^{\circ} \mathrm{C}\right)$. Thus, we investigated how the presence of PC in the water phase affects the dimerization of Azure B (structure shown in Fig. 5).

It is well known that thiazine dyes form dimers. For example, thionine, Azure A and Methylene blue form H-aggregates (face-to-face dimers), resulting in a blue shift in the absorption spectrum [58,59], and similar behaviour was reported previously also for Azure B, reporting also the dimerization constants for water and water $+8 \mathrm{M}$ urea [39]. To understand the behaviour of Azure B in presence of PC or $\mathrm{PC}+8 \mathrm{M}$ urea, UV-vis spectra were acquired for the Azure B solutions at various concentrations, as shown in Fig. 6 . The absorbance at $650 \mathrm{~nm}$ attributed to monomeric Azure B for water saturated with PC shows a linear region in the concentration range between 0 and ca. $100 \mu \mathrm{M}$ (the maxim of absorbance in the absence of PC or urea is $646 \mathrm{~nm}$ [39]). For solutions of $8 \mathrm{M}$ urea (also PC saturated), the maximum shifted to $649 \mathrm{~nm}$ and displayed a linear region in the concentration range between 0 and ca. $400 \mu \mathrm{M}$. Beyond these concentrations, dimerization of
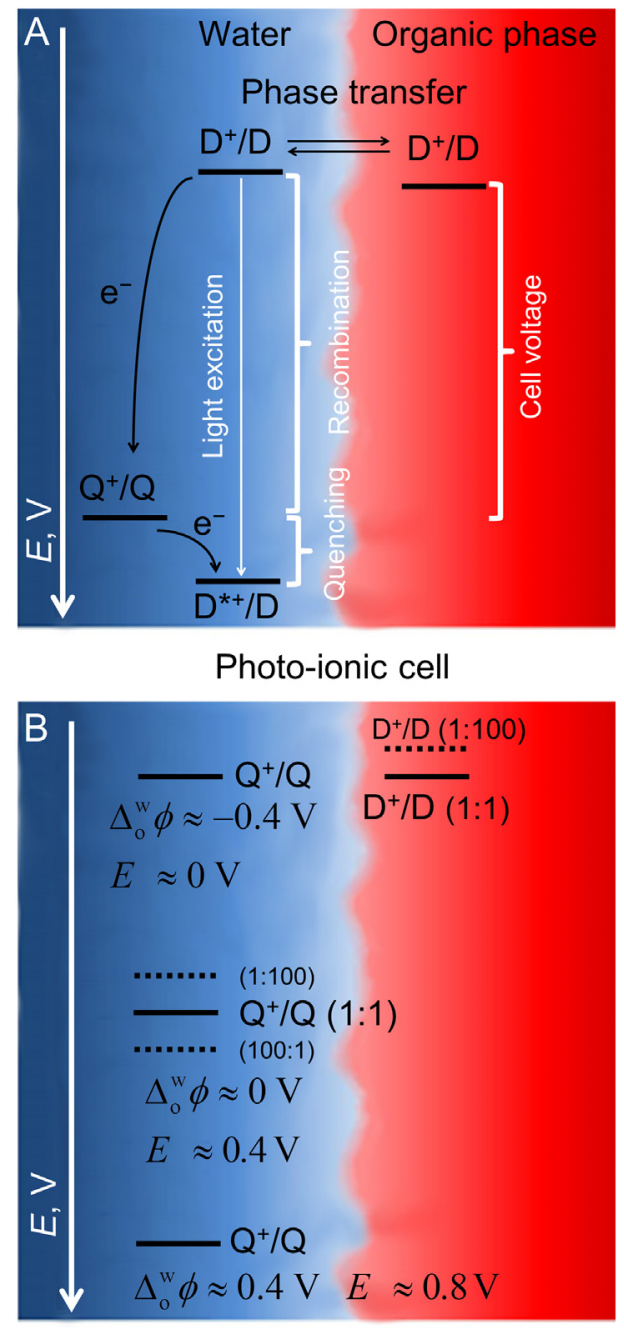

Fuel cell

Fig. 4. A) Potential levels of different species displaying the driving force for the quenching between sensitizer dye $\left(\mathrm{D}^{+}\right)$and quencher $(\mathrm{Q})$, driving force for the recombination in aqueous phase and the final cell voltage, assuming that the redox potential of the $\mathrm{D}^{+} / \mathrm{D}$ couple does not significantly change when transferred into the organic phase. B) Effect of the liquid-liquid interface polarisation on the fuel cell (see Fig. 2) voltage $E$ considering a hypothetical system with the standard potential of the dye in the organic phase $\left[E_{\mathrm{D}^{+} / \mathrm{D}}^{\mathrm{o}-}\right]_{\mathrm{SHE}}^{\mathrm{o}}=0 \mathrm{~V}$ while the standard potential of the quencher in the aqueous phase $\left[E_{\mathrm{Q}^{+} / \mathrm{Q}}^{\mathrm{o}}\right]_{\mathrm{SHE}}^{\mathrm{W}}=0.4 \mathrm{~V}$. Note also that the Nernst potentials of the $\mathrm{D}^{+} / \mathrm{D}$ and $\mathrm{Q}^{+} / \mathrm{Q}$ couple depend on the ratios of oxidized and reduced species. Typically, the photocharging reaction can reduce the ratio of $S^{+} / S$ down to $1: 100$, resulting in the $120 / \mathrm{n} \mathrm{mV}$ downward shift on the Nernst potential of the $\mathrm{D}^{+} / \mathrm{D}$ couple from the formal potential (typically the number of electrons $n=2$ ). If the quencher is in significant excess to the sensitizer, the ratio of $Q^{+} / Q$ couple can also remain close to 1:100 or 1:10. Ideally, equal amounts of quencher and sensitizer would be required to obtain maximum cell voltage, but this can significantly reduce the rate of quenching reaction and increase recombination losses.<smiles></smiles>

Fig. 5. Structure of the Azure B. 

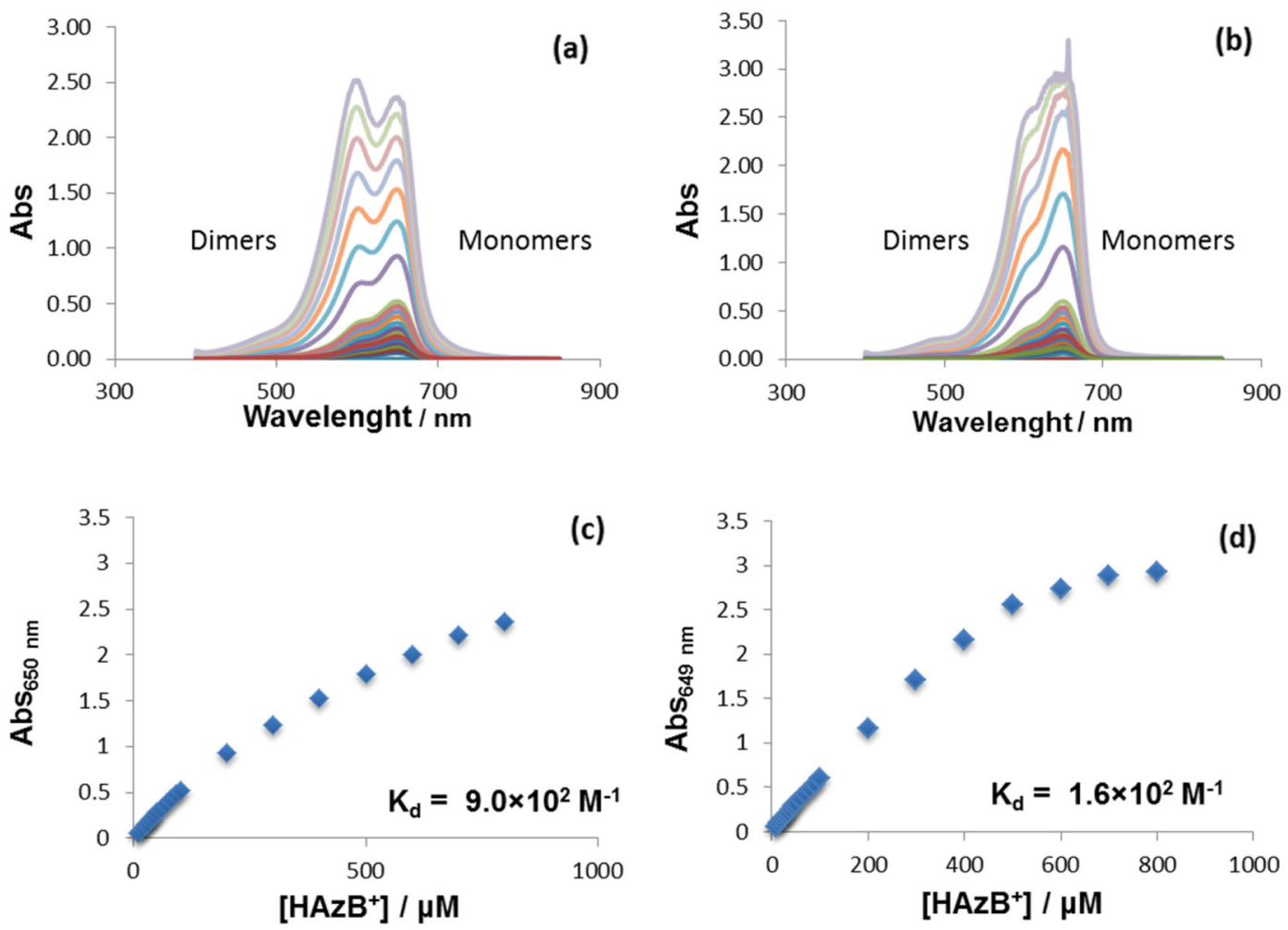

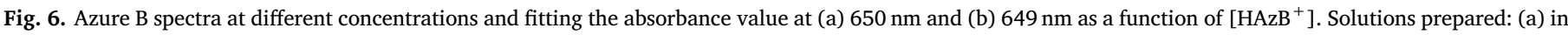
water saturated with PC; (b) in $8 \mathrm{M}$ urea water solution saturated with PC. The path length was $0.1 \mathrm{~cm}$.

$\mathrm{HAzB}^{+}$is expected to occur:

$2 \mathrm{HAzB}^{+} \rightleftarrows[\mathrm{HAzB}]_{2}^{2+}$

The dimerization constants were obtained as reported previously [39], and are compared with previous results in Table 1. These results shown that PC dissolved in water can also break the water structure and behave as a chaotropic agent, reducing the aggregation of hydrophobic dyes. Combining both urea and PC leads to further decrease of the dimerization constant $K_{\mathrm{d}}$. This effect can be used for advantage in the development of photo-ionic cells.

\subsection{Partition coefficients}

The partition coefficient of the neutral dye is one of the most important parameters and should preferably be $>10$ and optimally $>100$ [38], as partition of the reduced dye $\mathrm{H}_{2} \mathrm{AzB}$ is required to separate it from the oxidized quencher $\mathrm{Na}[\mathrm{Co}(\mathrm{III}) \mathrm{EDTA}]$ to store the charge in the photo-ionic cell. Additionally, $\mathrm{Na}$ [Co(III)EDTA] generated in the photoreaction should remain in the water phase, and the reduced dye will transfer to the organic phase. $\mathrm{THxA}^{+}$was chosen as a common ion and supporting electrolyte to keep the cobalt complex in the aqueous phase and increase extraction efficiency of the leuco-dye [39]. Partition coefficients were measured as described earlier [38,39]. Table 2 presents the measured partition coefficients of both the reduced leuco-dye $\mathrm{H}_{2} \mathrm{AzB}$ (measured from the maximum absorbance of $255 \mathrm{~nm}$ for all the

Table 1

Dimerization constants of Azure B.

\begin{tabular}{ll}
\hline Solvent & $K_{\mathrm{d}, \mathrm{M}^{-1}}$ \\
\hline Water & 2700 \\
Water + 8 M urea & 330 \\
Water (PC saturated) & 900 \\
Water + 8 M urea (PC saturated) & 160
\end{tabular}

Table 2

Partition coefficients for leuco-Azure B and $\mathrm{HAzB}^{+}$as the chloride salt.

\begin{tabular}{lll}
\hline & \multicolumn{2}{l}{ Partition coefficient, $K \mathrm{p}^{\mathrm{o} / \mathrm{w}}$} \\
\cline { 2 - 3 } & Without urea & With urea \\
\hline Azure B leuco form & & \\
DCE & 6.1 & 4.6 \\
PC & 4.9 & 4.4 \\
$\mathrm{HAzB}{ }^{+} \mathrm{Cl}^{-}$ & & \\
PC & 36 & 3.8 \\
\hline
\end{tabular}

cases) and for $\mathrm{HAzB}^{+}$(measured from the absorbance maximums of $\lambda_{\mathrm{W} / \mathrm{DCE}}=646 \mathrm{~nm}, \quad \lambda_{\mathrm{W}(\mathrm{u}) / \mathrm{DCE}}=651 \mathrm{~nm}, \quad \lambda_{\mathrm{W}(\mathrm{u}) / \mathrm{PC}}=650 \mathrm{~nm}, \quad \lambda_{\mathrm{W} /}$ $\mathrm{PC}=649 \mathrm{~nm}$ ) for both water/DCE and water/PC interfaces with and without urea. Presence of urea in the aqueous phase did not have a great effect on partition coefficient with PC saturated water. Unfortunately, the partition coefficient of leuco-Azure B in all cases is $<10$, resulting in less efficient charge-separation following the photoreaction. Partition coefficient of the $\mathrm{HAzB}^{+}$between water and DCE depends on the Galvani potential difference [36], while the partition coefficient of the $\mathrm{HAzB}^{+}$between water and PC does not depend significantly on the Galvani potential difference, but will depend on the counter ion as well as other ions present in the system (vide infra).

\subsection{Kinetics}

To check the rates of the photoreactions, the absorption of the Azure $B$ in the water phase was measured after a particular irradiation time. The two-phase system was irradiated with red LED light under vigorous mixing for fixed intervals of time, and the absorption was measured after the phases had separated. A new experiment with fresh solutions was performed for each specific time until the absorbance reached a minimum. After that, the mixing was continued to favor mass transport 

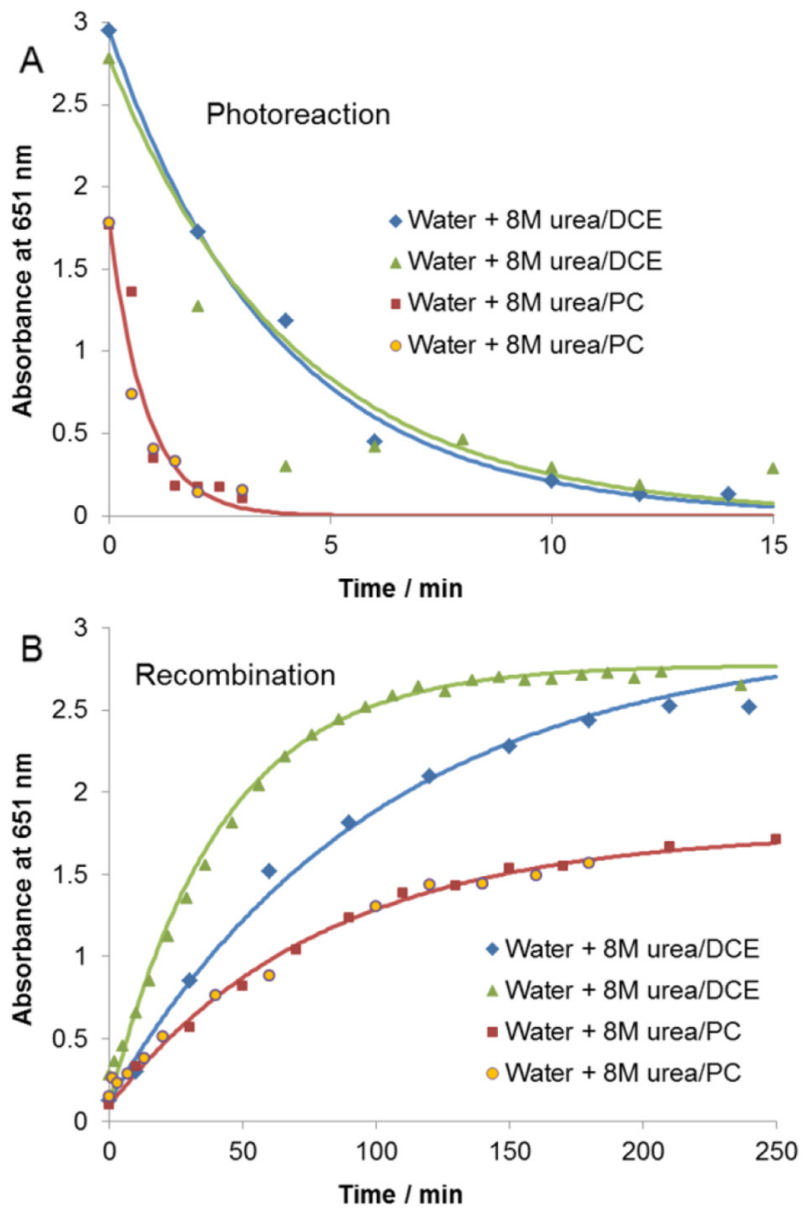

Fig. 7. Absorbance of the cell A in Scheme 1 (with $50 \mu \mathrm{M} \mathrm{HAzB}^{+}$and $50 \mathrm{mM}$ $\mathrm{Na}_{2}$ [Co(II)EDTA]) at $651 \mathrm{~nm}$ for fixed intervals of excitation time A) during irradiation with red LED $\left(1234 \mathrm{~W} \cdot \mathrm{m}^{-2}\right.$ at $\left.625 \mathrm{~nm}\right)$ to investigate the photoreaction and B) during recombination in the dark. Experiments were repeated twice, with significant variation for DCE. The optical path length was $1 \mathrm{~cm}$ and the $\mathrm{HAzB}^{+}$concentration was diluted by half while keeping the dye/quencher ratio constant to avoid saturation of the spectrophotometer. Solid lines show the theoretical curves with the apparent rate constants of photoreaction of $0.004 \mathrm{~s}^{-1}$ for DCE and $0.02 \mathrm{~s}^{-1}$ for PC and the apparent rate constants of recombination of $1.6 \times 10^{-4}$ or $4 \times 10^{-4} \mathrm{~s}^{-1}$ for DCE and $2.1 \times 10^{-4} \mathrm{~s}^{-1}$ for PC.

across the interface and to measure the recombination rate. The results are displayed in Fig. 7. Absorbance of the aqueous phase was significantly higher in the presence of DCE, as $\mathrm{HAzB}^{+}$can significantly partition into the $\mathrm{PC}$ phase. The $\mathrm{HAzB}^{+}$partition coefficient of 0.72 was obtained for the cell configuration 2 in Scheme 1, highlighting that the partition coefficients of ionic species can vary significantly depending on the composition of the solutions. The same experiment could not be performed for water/PC interface due to high partition coefficient of $\mathrm{HAzB}^{+}$. In this case, the photoreaction time was comparable with the water $+8 \mathrm{M}$ urea/PC system, as the solution in the cell is bleached upon formation of photoproducts. The rate of reaction is much faster when PC is utilized as the organic solvent, requiring approximately $3 \mathrm{~min}$. While with DCE the photoreaction was finished after approximately $12 \mathrm{~min}$. The recombination reactions proceed also at higher rate when DCE is used as the organic solvent instead of PC.

The integrated rate law expression $k t=\ln (a /(a-x))$, where $a$ is the initial amount of $\mathrm{HAzB}^{+}, x$ is the amount of the photoproduct $\mathrm{H}_{2} \mathrm{AzB}$ and $k$ is the apparent first order rate constant, was used to estimate the rate of the photoreaction under these conditions. For PC, the rate was estimated as $0.015 \mathrm{~s}^{-1}$, while for DCE solution the rate was almost one order of magnitude slower, 0.004 or $0.003 \mathrm{~s}^{-1}$. The rate of
Table 3

Voltage comparison.

\begin{tabular}{llll}
\hline Voltage, $\mathrm{mV}$ & $\begin{array}{l}\text { Water }+8 \mathrm{M} \text { urea / } \\
\text { DCE }\end{array}$ & $\begin{array}{l}\text { Water }+8 \mathrm{M} \text { urea / } \\
\text { PC }\end{array}$ & Water / PC \\
\hline Red LED charged & 190 & 280 & \\
Fully charged & 259 & 591 & 574 \\
\hline
\end{tabular}

recombination reaction with DCE was estimated similarly as $1.6 \times 10^{-4}$ or $3.0 \times 10^{-4} \mathrm{~s}^{-1}$, while the rate in PC is of similar magnitude, $1.6 \times 10^{-4}$ or $2.1 \times 10^{-4} \mathrm{~s}^{-1}$ considering total amount of $\mathrm{H}_{2} \mathrm{AzB}$ in the system (now $a$ is the total initial amount of $\mathrm{H}_{2} \mathrm{AzB}$ while $x$ is the total amount of $\mathrm{HAzB}^{+}$). The apparent differences in Fig. 7B are due to the significant partitioning of $\mathrm{HAzB}^{+}$into the PC phase. If curves are normalized by the maximum absorbance, they show very similar behaviour. Of course, the apparent rate constants depend on the stirring rate, light intensity, concentrations of quenchers and reactants etc. Here, same reaction conditions were used to compare PC and DCE.

\subsection{Voltage measurements}

One of the parameters to determine the efficiency of the photo-ionic cell is the voltage. For the Azure B/Co(EDTA) system voltage would be determined by Eq. (19). Table 3 shows the measured voltages after photoreaction under red LED illumination (Scheme 1B) and for fully charged (Scheme 1C) cells. The differences between fully charged (Scheme 1C) and photo-charged cells (Scheme 1B) are simply due to the larger shift of the Nernst potential of the aqueous phase. During photocharging reactions, most of the Azure B is reduced, while only maximum $200 \mu \mathrm{M}$ of the Co(II)EDTA of the total of $100 \mathrm{mM}$ is oxidized to Co(III)EDTA, while the fully charged cell contains almost solely Co(III) EDTA. For the fully charged cell, the cell voltage should increase by ca. $240 \mathrm{mV}$ as the ratio of $\mathrm{Co}(\mathrm{III}) /(\mathrm{II})$ changes from 1:100 to 100:1. However, with DCE a shift of only $60 \mathrm{mV}$ is obtained. The cell voltage observed with PC corresponds better with the theoretical expectations. As expected, the voltage of the fully charged cell increases by $300 \mathrm{mV}$ when compared with photo charging experiments, and the voltage of the cell where PC was used as the organic solvent (both with and without $8 \mathrm{M}$ urea in the water phase) is much higher than for the water $+8 \mathrm{M}$ urea/DCE cell. These results show that to optimize the cell voltage, the ratio of $\mathrm{Co}(\mathrm{III}) /(\mathrm{II})$ should be as high as possible while maintaining the high rate of the photoreduction of the Azure B.

\subsection{Two-electrode cell voltammetry}

Fig. 8 shows the two-electrode cell CVs of the different systems measured with the cell shown in the inset. The CVs were recorded with the carbon felt electrode in the aqueous phase as the "working electrode" (WE) and the electrode in the organic phase as the "counter electrode" (CE), i.e. the potential $E$ in Fig. 8 is the potential difference between the aqueous and organic phase electrodes. In this configuration, a positive current corresponds to an oxidation of Co(II)EDTA at the aqueous electrode and reduction of Azure B in the organic phase, while a negative current corresponds to a reduction on the electrode in the aqueous phase and an oxidation on the electrode in the organic phase. All CVs show a diffusion controlled broad wave. In all cases, the currents are mostly limited by the diffusion of leuco-Azure B in the organic phase. For photocharged cells, the broadness of the wave stems from the diffusion limitations of both the leuco-Azure B and Co(III) EDTA, while fully charged cells containing mostly Co(III)EDTA show sharper peaks because now only the diffusion of the dye is limiting the reaction. Additionally, large $i R$ drop due to the poorly conductive organic phase contributes to peak broadening. The CVs recorded with the cell containing DCE show also a strong adsorption type peak, indicating that Azure B can adsorb on the carbon felt electrode in the DCE phase. 

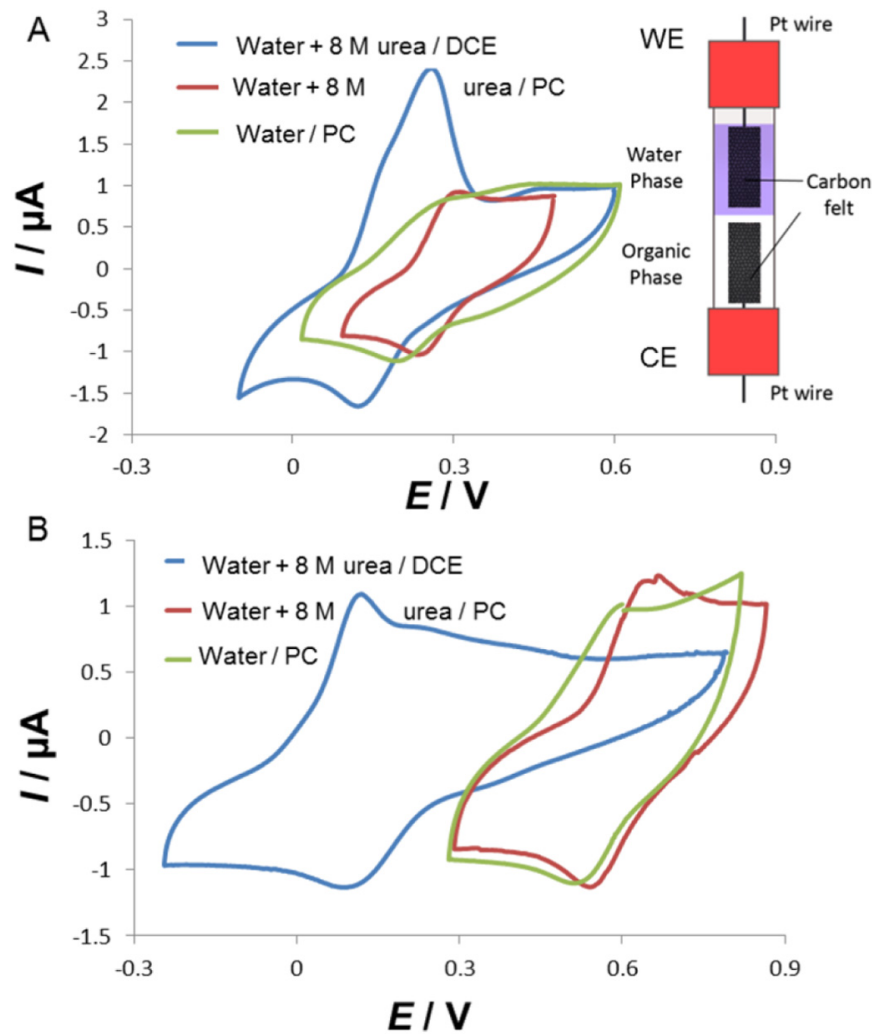

Fig. 8. A) Red LED charged cell voltammograms comparison (Scheme 1 B) for water $+8 \mathrm{M}$ urea/PC, water/PC and water $+8 \mathrm{M}$ urea/DCE interface. B) Fully charged cell voltammograms comparison (Scheme 1C) for water $+8 \mathrm{M}$ urea/ $\mathrm{PC}$, water/PC and water $+8 \mathrm{M}$ urea/DCE interface, measured with the 2electrode cell shown in the inset at a scan rate of $25 \mathrm{mV} / \mathrm{s}$. CVs are recorded with the electrode in the two-electrode configuration with the aqueous phase as the "working electrode", i.e. the potential $E$ is the potential of the electrode in the aqueous phase vs. the potential in the organic phase.

The cell voltages for different cases can be estimated theoretically from Eq. (19), and the results are shown in Fig. 9. For the photo-charged cell, the Nernst potential of the organic phase is expected to shift ca. $60 \mathrm{mV}$ negatively from the standard potential, as Azure B is present mostly in the reduced form (corresponding to a ratio of 1:100 of $\mathrm{HAzB}^{+}$/ $\mathrm{H}_{2} \mathrm{AzB}$ with the number of electrons of two), while the Co(III)/(II) couple

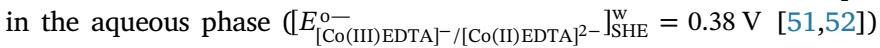
has the Nernst potential of $0.26 \mathrm{~V}$ or even below, as there is $<1 \mathrm{mM}$ of $\mathrm{Co}$ (III) produced in the photoreaction (Co(III)/Co(II) ration of $<1: 100$ shifting the Nernst potential by ca. $120 \mathrm{mV}$ negative). For fully charged cells the Nernst potential of the aqueous phase is considered to increase

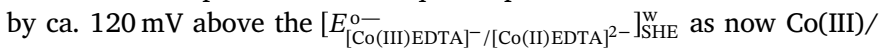
Co(II) ratio is higher than 100:1.

When $\mathrm{THxA}^{+}$is used to fix the Galvani potential difference of the DCE-water interface to $\Delta_{\mathrm{DCE}}{ }^{\mathrm{w}} \phi=-0.46 \mathrm{~V}$ [53], a cell voltage of $-0.36 \mathrm{~V}$ is expected, in disagreement with the experimental values. However, addition of urea affects the transfer energies of $\mathrm{HAzB}^{+}$, $\mathrm{THxA}^{+}$and $\mathrm{H}^{+}$, and could even affect the formal potentials of the redox couples in aqueous phase, allowing the discharging of the cell albeit at low cell voltages. For the photo charged cell with PC an overall cell voltage of ca. $0.3 \mathrm{~V}$ is expected, and this value increases to $0.54 \mathrm{~V}$ for a fully charged cell. These values correlate very well with the measured cell voltages presented in Table 3 .

\subsection{System efficiency and charge storage capacity}

Azure B absorbs light at ca. 550 to $650 \mathrm{~nm}$ range. Hence, it has the potential to absorb roughly $15 \%$ of the solar irradiation. Under
A
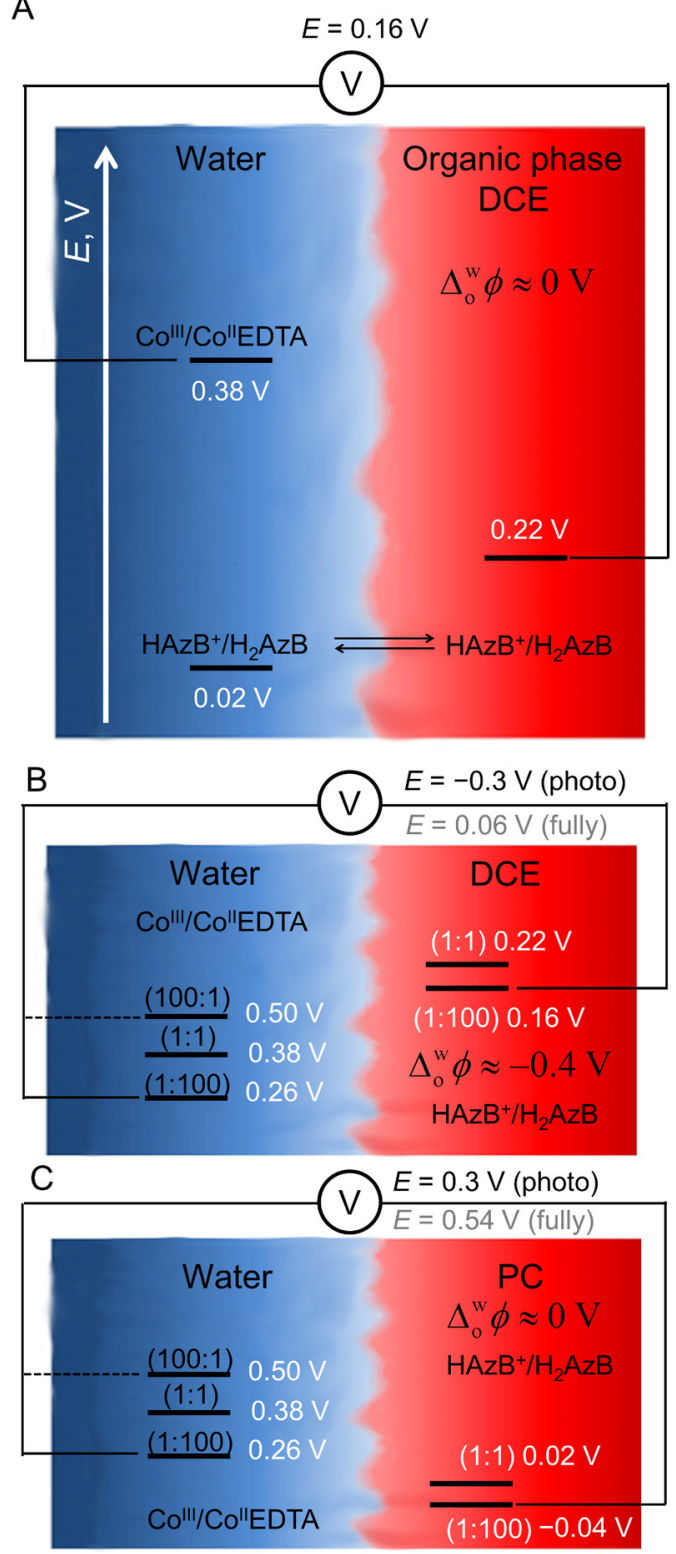

Fig. 9. Potential diagram of the different situations: Azure B-Co(EDTA) system in DCE with $\Delta_{\mathrm{o}}{ }^{\mathrm{w}} \phi=0 \mathrm{~V}$ (unfavorable as negative Galvani potential difference is required to keep $\mathrm{HAzB}^{+}$in the aqueous phase), Azure B-Co(EDTA) system in DCE with $\Delta_{\mathrm{o}}{ }^{\mathrm{w}} \phi=-0.4 \mathrm{~V}$ also considering different ratios of Ox/Red, and the

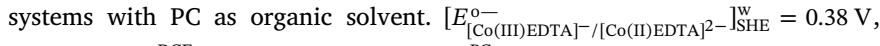

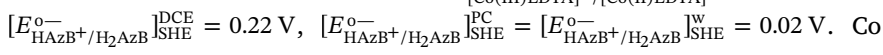
(III)/Co(II) ratios of $100: 1$ and 1:100 correspond to fully charged and photocharged cells, respectively. For both cases the $\mathrm{HAzB}^{+} / \mathrm{H}_{2} \mathrm{AzB}$ ratio is $1: 100$. The cell voltages for photo charged and fully charged cells are shown next to the voltage meter.

optimized conditions, a quantum yield of $13 \%$ has been demonstrated [39]. Here, the theoretical efficiency of the fuel cell can be estimated considering that the photon energy at $600 \mathrm{~nm}$ is roughly $2.1 \mathrm{eV}$ while the cell voltage of the system with propylene carbonate can reach $0.6 \mathrm{~V}$, i.e. the theoretical efficiency of $30 \%$ is expected for this step. In practice, similar flow batteries show energy efficiencies (ratio of energy output and input upon charge and discharge) up to $80 \%$, so the efficiency of the discharging step can reach $90 \%$ for well optimized system [7-10]. These rough estimations show that $0.5 \%$ of the solar energy could be converted into electricity with the Azure B based system. On the other hand, the efficiency for conversion of the irradiation of the 
Table 4

Comparison of photo-ionic cells for DCE and PC.

\begin{tabular}{|c|c|c|}
\hline Interface & + & - \\
\hline $\begin{array}{l}\text { Water }+8 \mathrm{M} \text { urea / } \\
\quad \text { DCE }\end{array}$ & $\begin{array}{l}\text { Small dimerization } \\
\text { constant } \\
\text { Fast phase separation }\end{array}$ & $\begin{array}{l}\text { Low voltage } \\
\text { Slower rate of } \\
\text { photoreaction } \\
\text { Small partition coefficient } \\
\text { Toxic }\end{array}$ \\
\hline Water $+8 \mathrm{M}$ urea / PC & $\begin{array}{l}\text { High rate of } \\
\text { photoreaction } \\
\text { Small dimerization } \\
\text { constant } \\
\text { High voltage } \\
\text { Non-toxic }\end{array}$ & $\begin{array}{l}\text { Low charge } \\
\text { Small partition coefficient } \\
\text { Long time for phase } \\
\text { separation }\end{array}$ \\
\hline Water / PC & $\begin{array}{l}\text { High rate of } \\
\text { photoreaction } \\
\text { High voltage } \\
\text { Non-toxic }\end{array}$ & $\begin{array}{l}\text { Small partition coefficient } \\
\text { Long time for phase } \\
\text { separation }\end{array}$ \\
\hline
\end{tabular}

550 to $650 \mathrm{~nm}$ range is $3.3 \%$. Instead of comparison with solar panels, the photo-ionic cells should be compared with photovoltaic cells coupled with a battery, as the photo-ionic cells are producing electricity upon demand. However, this rough calculation highlights that for a system with reasonable efficiency, multiple dyes absorbing light over the whole range of the solar spectrum would be required. Additionally, quantum yield of only $13 \%$ needs to be improved to realize practical systems.

The amount of energy that can be stored depends on the concentration of the dye. For cell A in Scheme 1 the charge storage density is only $5 \mathrm{~m} \mathrm{Ah} / \mathrm{L}$. For concentrations of $10 \mathrm{mM}$ of the dye the charge storage density of $0.5 \mathrm{Ah} / \mathrm{L}$, and $100 \mathrm{mM}$ would enable storage of $5.4 \mathrm{Ah} / \mathrm{L}$. This is $20 \%$ of the charge storage capacity of a typical vanadium redox flow battery [7-10]. The energy storage density depends on the cell voltage. Considering the cell voltage of $0.6 \mathrm{~V}$, the $100 \mathrm{mM}$ dye solution is able to store $3.2 \mathrm{Wh} / \mathrm{L}$, so $10 \%$ of the capacity of a typical vanadium redox flow battery [7-10]. However, reaching $100 \mathrm{mM}$ dye concentrations without aggregation will be a challenge.

\section{Conclusions}

Table 4 presents the advantages and disadvantages of each studied system. PC with and without urea displays better kinetics and higher cell voltage. One of the most severe drawbacks is the slow separation of phases after mixing. It is crucial that phases should be separated as fast as possible to minimize the recombination losses, this could be done with a phase separator as for example used in the oil industry. However, the possibility for obtaining cell voltages of up to $0.6 \mathrm{~V}$ outweighs these disadvantages. The results also show that in addition to the dye and the quencher, the solvent can have drastic effects on the performance of the photo-ionic cells.

When the efficiency of the system to convert solar energy into electricity is considered, it becomes apparent that quantum yield has to be improved for the system to become practical. Additionally, multiple dyes would be required to take advantage of the whole range of the solar spectrum. Thirdly, practical energy storage densities are achieved if the dye concentrations can be improved by 2-3 orders of magnitude. Also, power density depends on the concentration, as higher concentrations are able to provide more currents.

\section{Acknowledgements}

E.V. is grateful for the scholarship from the Federal Commission for Scholarships for Foreign Students FCS, Switzerland. P.P. acknowledges the financial support from the Swiss National Science Foundation under Grant Ambizione Energy 160553.

\section{References}

[1] C. Battaglia, A. Cuevas, S. De Wolf, High-efficiency crystalline silicon solar cells: status and perspectives, Energy Environ. Sci. 9 (2016) 1552-1576, http://dx.doi. org $/ 10.1039 /$ C5EE03380B.

[2] M. Roeb, M. Neises, N. Monnerie, C. Sattler, R. Pitz-Paal, Technologies and trends in solar power and fuels, Energy Environ. Sci. 4 (2011) 2503, http://dx.doi.org/10. 1039/c1ee01128f.

[3] S. Sharma, Bulkesh Siwach, S.K. Ghoshal, D. Mohan, Dye sensitized solar cells: from genesis to recent drifts, Renew. Sust. Energ. Rev. 70 (2017) 529-537, http://dx.doi. org/10.1016/j.rser.2016.11.136.

[4] L. Kavan, Electrochemistry and dye-sensitized solar cells, Curr. Opin. Electrochem. 2 (2017) 88-96, http://dx.doi.org/10.1016/j.coelec.2017.03.008.

[5] M. Freitag, G. Boschloo, The revival of dye-sensitized solar cells, Curr. Opin. Electrochem. 2 (2017) 111-119, http://dx.doi.org/10.1016/j.coelec.2017.03.011.

[6] B. Dunn, H. Kamath, J.-M. Tarascon, Electrical energy storage for the grid: a battery of choices, Science 334 (2011) 928-935, http://dx.doi.org/10.1126/science. 1212741.

[7] C.R. Dennison, H. Vrubel, V. Amstutz, P. Peljo, K.E. Toghill, H.H. Girault, Redox flow batteries, hydrogen and distributed storage, Chimia 69 (2015) 753-758, http://dx.doi.org/10.2533/chimia.2015.753.

[8] M.L. Perry, A.Z. Weber, Advanced redox-flow batteries: a perspective, J. Electrochem. Soc. 163 (2016) A5064-A5067, http://dx.doi.org/10.1149/2. 0101601jes.

[9] G.L. Soloveichik, Flow batteries: current status and trends, Chem. Rev. 115 (2015) 11533-11558, http://dx.doi.org/10.1021/cr500720t.

[10] J. Noack, N. Roznyatovskaya, T. Herr, P. Fischer, The chemistry of redox-flow batteries, Angew. Chem. Int. Ed. 54 (2015) 9776-9809, http://dx.doi.org/10.1002/ anie.201410823.

[11] D. Das, T.N. Veziroglu, Advances in biological hydrogen production processes, Int. J. Hydrog. Energy 33 (2008) 6046-6057, http://dx.doi.org/10.1016/j.ijhydene. 2008.07.098.

[12] K.S. Joya, Y.F. Joya, K. Ocakoglu, R. van de Krol, Water-splitting catalysis and solar fuel devices: artificial leaves on the move, Angew. Chem. Int. Ed. 52 (2013) 10426-10437, http://dx.doi.org/10.1002/anie.201300136.

[13] L. Rivier, P. Peljo, L.A.C. Vannay, G.C. Gschwend, M.A. Méndez, C. Corminboeuf, M.D. Scanlon, H.H. Girault, Photoproduction of hydrogen by decamethylruthenocene combined with electrochemical recycling, Angew. Chem. Int Ed. 56 (2017) 2324-2327, http://dx.doi.org/10.1002/anie.201610240.

[14] L. Rivier, T.J. Stockmann, M.A. Méndez, M.D. Scanlon, P. Peljo, M. Opallo, H.H. Girault, Decamethylruthenocene hydride and hydrogen formation at liquid|liquid interfaces, J. Phys. Chem. C 119 (2015) 25761-25769, http://dx.doi. org/10.1021/acs.jpcc.5b08148.

[15] S. Das, W.M.A. Wan Daud, A review on advances in photocatalysts towards $\mathrm{CO}_{2}$ conversion, RSC Adv. 4 (2014) 20856-20893, http://dx.doi.org/10.1039/ C4RA01769B.

[16] A. Harriman, Prospects for conversion of solar energy into chemical fuels: the concept of a solar fuels industry, Philos. Transact. A Math. Phys. Eng. Sci. 371 (2013) 20110415, , http://dx.doi.org/10.1098/rsta.2011.0415.

[17] D. Kang, T.W. Kim, S.R. Kubota, A.C. Cardiel, H.G. Cha, K.-S. Choi, Electrochemical synthesis of photoelectrodes and catalysts for use in solar water splitting, Chem. Rev. 115 (2015) 12839-12887, http://dx.doi.org/10.1021/acs.chemrev.5b00498.

[18] M.R. Shaner, H.A. Atwater, N.S. Lewis, E.W. McFarland, A comparative technoeconomic analysis of renewable hydrogen production using solar energy, Energy Environ. Sci. 9 (2016) 2354-2371, http://dx.doi.org/10.1039/C5EE02573G.

[19] S. Protti, A. Albini, N. Serpone, Photocatalytic generation of solar fuels from the reduction of $\mathrm{H}_{2} \mathrm{O}$ and $\mathrm{CO}_{2}$ : a look at the patent literature, Phys. Chem. Chem. Phys. (2014), http://dx.doi.org/10.1039/C4CP02828G.

[20] W.J. Albery, Development of photogalvanic cells for solar energy conservation, Acc. Chem. Res. 15 (1982) 142-148, http://dx.doi.org/10.1021/ar00077a003.

[21] A.K. Jana, Solar cells based on dyes, J. Photochem. Photobiol. A Chem. 132 (2000) 1-17, http://dx.doi.org/10.1016/S1010-6030(99)00251-8.

[22] E. Rabinowitch, The photogalvanic effect I. The photochemical properties of the thionine-iron system, J. Chem. Phys. 8 (1940) 551-559, http://dx.doi.org/10. 1063/1.1750711.

[23] E. Rabinowitch, The photogalvanic effect II. The photogalvanic properties of the thionine-iron system, J. Chem. Phys. 8 (1940) 560-566, http://dx.doi.org/10. 1063/1.1750712.

[24] K.G. Mathai, E. Rabinowitch, Studies of thionine-ferrous iron reaction in a heterogeneous system, J. Phys. Chem. 66 (1962) 663-664, http://dx.doi.org/10.1021/ j100810a021.

[25] V. Srinivasan, E. Rabinowitch, Photochemical reduction of thionine by cobalt (II) EDTA complex in water-ether emulsion, J. Chem. Phys. 52 (1970) 1165-1168, http://dx.doi.org/10.1063/1.1673112.

[26] W.J. Albery, P.N. Bartlett, A.W. Foulds, F.A. Souto-Bachiller, R. Whiteside, Photogalvanic cells. Part 14. The synthesis and characterization of disulphonated thionines, J. Chem. Soc. Perkin Trans. 2 (1981) 794-800, http://dx.doi.org/10. 1039/P29810000794.

[27] W.J. Albery, M.D. Archer, Optimum efficiency of photogalvanic cells for solar energy conversion, Nature 270 (1977) 399-402, http://dx.doi.org/10.1038/ 270399a0.

[28] W.J. Albery, P.N. Bartlett, A.M. Lithgow, J.L. Riefkohl, L.A. Rodriguez, L. Romero, F.A. Souto, Synthesis and characterization of disulfonated thionines. Redox mediators for electrochemical energy conversion systems, J. Organomet. Chem. 50 (1985) 596-603, http://dx.doi.org/10.1021/jo00205a009. 
[29] J.E. Halls, J.D. Wadhawan, Photogalvanic cells, principles and perspectives, Encyclopedia of Applied Electrochemistry, Springer New York, New York, NY, 2014, pp. 1556-1578, , http://dx.doi.org/10.1007/978-1-4419-6996-5_521.

[30] R.A. Mackay, M. Grätzel, The photoreduction of thionine and surfactant thionine by iron(II) in anionic micelles and microemulsions, Ber. Bunsenges. Phys. Chem. 89 (1985) 526-530, http://dx.doi.org/10.1002/bbpc.19850890513.

[31] M. Grätzel, Artificial photosynthesis, energy- and light-driven electron transfer in organized molecular assemblies and colloidal semiconductors, Biochim. Biophys. Acta, Rev. Bioenerg. 683 (1982) 221-244, http://dx.doi.org/10.1016/03044173(82)90002-7.

[32] J.H. Fendler, E.J. Fendler, Catalysis in Micellar and Macromolecular Systems, Academic Press, 1975

[33] D. Attwood, A.T. Florence, Surfactant Systems, Springer Netherlands, Dordrecht, 1983, http://dx.doi.org/10.1007/978-94-009-5775-6.

[34] K. Rohatgi-Mukherjee, R. Chaudhuri, B.B. Bhowmik, Molecular interaction of phenosafranin with surfactants and its photogalvanic effect, J. Colloid Interface Sci. 106 (1985) 45-50, http://dx.doi.org/10.1016/0021-9797(85)90378-9.

[35] J.E. Halls, J.D. Wadhawan, Photogalvanic cells based on lyotropic nanosystems: towards the use of liquid nanotechnology for personalised energy sources, Energy Environ. Sci. 5 (2012) 6541-6551, http://dx. doi.org/10.1039/C2EE03169H.

[36] P. Peljo, H.H. Girault, Liquid/liquid interfaces, Electrochemistry at, in: R.A. Meyers (Ed.), Encyclopedia of Analytical Chemistry, John Wiley \& Sons, Ltd., Chichester, UK, 2012, , http://dx.doi.org/10.1002/9780470027318.a5306.pub2.

[37] H.H. Girault, Electrochemistry at liquid-liquid interfaces, in: A.J. Bard, C.G. Zoski (Eds.), Electroanalytical Chemistry: A Series of Advances, Taylor \& Francis, Boca Raton, FL, 2010, pp. 1-104.

[38] M.A. Méndez, P. Peljo, M.D. Scanlon, H. Vrubel, H.H. Girault, Photo-ionic cells: two solutions to store solar energy and generate electricity on demand, J. Phys. Chem. C 118 (2014) 16872-16883, http://dx.doi.org/10.1021/jp500427t.

[39] R. Bourdon, P. Peljo, M.A. Méndez, A.J. Olaya, J. De Jonghe-Risse, H. Vrubel, H.H. Girault, Chaotropic agents boosting the performance of photoionic cells, J. Phys. Chem. C 119 (2015) 4728-4735, http://dx.doi.org/10.1021/acs.jpcc. 5b00334.

[40] P. Peljo, M.D. Scanlon, T.J. Stockmann, Simulations employing finite element method at liquid|liquid interfaces, Curr. Opin. Electrochem. (2017), http://dx.doi. org/10.1016/j.coelec.2017.09.011.

[41] J.A. Manzanares, C. Johans, J. Cervera, Distribution potential in electrified microemulsions with potential determining salts, J. Electroanal. Chem. (2017), http:// dx.doi.org/10.1016/j.jelechem.2017.08.049.

[42] C. Johans, M.A. Behrens, K.E. Bergquist, U. Olsson, J.A. Manzanares, Potential determining salts in microemulsions: interfacial distribution and effect on the phase behavior, Langmuir 29 (2013) 15738-15746, http://dx.doi.org/10.1021/ la404263v.

[43] Y. Liu, J. Xiao, L. Qiao, B. Liu, Amphiphilic mesoporous graphene mediated efficient photoionic cell, Carbon N. Y. 128 (2018) 134-137, http://dx.doi.org/10.1016/j. carbon.2017.11.062.

[44] P. Peljo, M. Bichon, H.H. Girault, Ion transfer battery: storing energy by transferring ions across liquid-liquid interfaces, Chem. Commun. 52 (2016) 9761-9764, http:// dx.doi.org/10.1039/C6CC04325A.

[45] F.P. Dwyer, E.C. Gyarfas, D.P. Mellor, The resolution and racemization of potassium ethylenediaminetetra-acetatocobaltate(III), J. Phys. Chem. 59 (1955) 296-297, http://dx.doi.org/10.1021/j150526a004.

[46] H.H. Girault, Analytical and Physical Electrochemistry, EPFL Press, Lausanne, 2004.

[47] T. Kakiuchi, Partition equilibrium of ionic components in two immiscible electrolyte solutions, in: A.G. Volkov, D.W. Deamer (Eds.), Liquid Interfaces: Theory and Methods, CRC Press, Boca Raton, 1996, pp. 1-18.

[48] I. Hatay, B. Su, F. Li, M.A. Méndez, T. Khoury, C.P. Gros, J.-M. Barbe, M. Ersoz, Z. Samec, H.H. Girault, Proton-coupled oxygen reduction at liquid-liquid interfaces catalyzed by cobalt porphine, J. Am. Chem. Soc. 131 (2009) 13453-13459, http:// dx.doi.org/10.1021/ja904569p.

[49] P. Peljo, T. Rauhala, L. Murtomäki, T. Kallio, K. Kontturi, Oxygen reduction at a water-1,2-dichlorobenzene interface catalyzed by cobalt tetraphenyl porphyrine - a fuel cell approach, Int. J. Hydrog. Energy 36 (2011) 10033-10043, http://dx.doi. org/10.1016/j.ijhydene.2011.05.042.

[50] A. Sabela, V. Mareček, Z. Samec, R. Fuoco, Standard Gibbs energies of transfer of univalent ions from water to 1,2-dichloroethane, Electrochim. Acta 37 (1992) 231-235, http://dx.doi.org/10.1016/0013-4686(92)85008-9.

[51] H. Ogino, K. Ogino, Redox potentials and related parameters of cobalt(III/II) complexes containing aminopolycarboxylates, Inorg. Chem. 22 (1983) 2208-2211, http://dx.doi.org/10.1021/ic00157a023.

[52] M.D. Arning, S.D. Minteer, 18 - electrode potentials, in: C.G. Zoski (Ed.), Handbook of Electrochemistry, Elsevier, Amsterdam, 2007, p. 813-XXIII, , http://dx.doi.org/ 10.1016/B978-044451958-0.50035-5.

[53] A.J. Olaya, M.A. Méndez, F. Cortes-Salazar, H.H. Girault, Voltammetric determination of extreme standard Gibbs ion transfer energy, J. Electroanal. Chem. 644 (2010) 60-66, http://dx.doi.org/10.1016/j.jelechem.2010.03.030.

[54] P. Peljo, L. Murtomäki, T. Kallio, X.-J. Xu, M. Meyer, C.P. Gros, J.M. Barbe, H.H. Girault, K. Laasonen, K. Kontturi, Biomimetic oxygen reduction by cofacial porphyrins at a liquid-liquid interface, J. Am. Chem. Soc. 134 (2012) 5974-5984.

[55] S. Moelbert, B. Normand, P. De Los Rios, Kosmotropes and chaotropes: modelling preferential exclusion, binding and aggregate stability, Biophys. Chem. 112 (2004) 45-57, http://dx.doi.org/10.1016/j.bpc.2004.06.012.

[56] J.D. Hamlin, D.A.S. Phillips, A. Whiting, UV/visible spectroscopic studies of the effects of common salt and urea upon reactive dye solutions, Dyes Pigments 41 (1999) 137-142, http://dx.doi.org/10.1016/S0143-7208(98)00076-X.

[57] P. Mukerjee, A. Ghosh, The effect of urea on methylene blue, its self-association, and interaction with polyelectrolytes in aqueous solution, J. Phys. Chem. 67 (1963) 193-197, http://dx.doi.org/10.1021/j100795a047.

[58] A. Ghanadzadeh Gilani, T. Ghorbanpour, M. Salmanpour, Additive effect on the dimer formation of thiazine dyes, J. Mol. Liq. 177 (2013) 273-282, http://dx.doi. org/10.1016/j.molliq.2012.09.005.

[59] K. Patil, R. Pawar, P. Talap, Self-aggregation of methylene blue in aqueous medium and aqueous solutions of $\mathrm{Bu}_{4} \mathrm{NBr}$ and urea, Phys. Chem. Chem. Phys. 2 (2000) 4313-4317, http://dx.doi.org/10.1039/b005370h. 